\title{
Reflexiones sobre la creación artística
}

\author{
Reflections on artistic creation
}

Terencia Inés Silva Rojas ${ }^{1}$

Docente jubilada de la Universidad de Vigo - Vigo, España

https://orcid.org/0000-0002-1894-4347

\section{RESUMEN}

Este trabajo tiene por objeto reflexionar sobre un tema que puede ser todo lo amplio que queramos, cubriendo varios campos de conocimiento y que atañe a todas las disciplinas artísticas. Nuestros objetivos son más modestos. No pretendemos llegar a una definición de la creación, simplemente acercarnos a este proceso complejo. Para cumplir con este propósito, elaboramos un cuestionario distribuido a un número reducido de artistas (doce en total) de diferentes campos: música, artes plásticas, literatura, etc.

\section{Palabras clave}

Creación, obra de arte, proceso creativo, receptor de la obra

\section{ABSTRACT}

This work aims to reflect on a topic that can be as broad as we want, covering various fields of knowledge and that concerns all artistic disciplines. Our objectives are more modest. Our intention is not to arrive at a definition of creation, but simply to approach this complex process. To fulfill this purpose, we prepared a questionnaire that was distributed to a small number of artists (twelve in total) from different fields of art: music, plastic arts, literature, etc.

\section{Keywords}

Creation, work of art, creative process, recipient of the work

\section{(c) $(1) \Theta \Theta$}

Cualquier uso que se haga de este artículo debe incluir: Autor / Título original de la publicación / ISSN.

1. Doctora (Lingüística General). tsilvarojas@gmail.com. 
Mi agradecimiento, por su colaboración desinteresada, a los artistas que han hecho posible este trabajo: Pilar Álvarez, Llorenç

Barber, Violeta Barrientos, Inmaculada Cárdenas, Augusto García Flores, Xoán-Xil López, Fátima Miranda, Jesús Otero-Yglesias, Montserrat Palacios, Ana María Rocha, Olga Verme-Mignot y José Villaba.

\section{INTRODUCCIÓN}

Propiciar una reflexión acerca de la creación artística sobre la base de las propuestas recogidas es nuestra intención. Para ello, las presentamos comparándolas o estableciendo similitudes o diferencias con un criterio transversal. Para un diseño teórico, sería necesario contar con un número mayor de entrevistas. Hemos intentado sencillamente aflorar sus experiencias como creadores, buscando plasmar sus preocupaciones, vivencias, planteamientos empíricos y teóricos en la realización de sus respectivas prácticas artísticas.

Los cuestionarios han sido respondidos por escrito, salvo el de Fátima Miranda que fue grabado $\mathrm{y}$ hemos transcrito. Los participantes representan maneras diferentes de desarrollar una actividad artística. Desde personas que la desarrollan de manera profesional, como la actividad fundamental de su quehacer y constituye su fuente de ingresos, a otro grupo constituido por artistas cuya creación no es ni su fuente principal de sustento ni su actividad profesional principal; y aunque se encuentra muy vinculada a aquella, se desarrolla de forma paralela. Otro grupo de creadores que contemplamos son aquellos cuya actividad profesional no tiene, ni ha tenido, relación directa con su actual actividad creadora.
El cuerpo del trabajo está organizado en secciones que recogen las respuestas de los entrevistados, sin corresponder exactamente ni al número ni al enunciado de las preguntas. De hecho, son seis epígrafes en total que corresponden a las nueve preguntas del cuestionario de la entrevista:

1) La obra de arte como creación corresponde a la primera pregunta: ¿Qué es para usted la creación?

2) La relación del artista con su obra corresponde a las preguntas dos, tres y cuatro: ¿Cree que hay momentos diferenciables en este proceso? ¿Qué condiciones requiere para poner en práctica un proceso creativo? ¿Tiene un modo de trabajo definido o este varía según la obra? Este epígrafe queda subdividido en tres apartados: 1) momentos diferenciables del proceso creativo; 2) condiciones para poner en práctica el proceso creativo; 3) modus operandi.

3) Diferencias entre los procesos creativos de las diferentes artes que corresponde a la pregunta seis: ¿Cree que hay diferencias en el proceso creativo de las diferentes artes?

4) La creación artística y otros tipos de creación que corresponde a la pregunta cinco: ¿Cree que hay diferencias entre la creación artística y otros tipos de creación?

5) La creación artística, acto de expresión o de comunicación que corresponde a la pregunta ocho: ¿Su creación artística es un acto de expresión, de comunicación, las dos cosas?

6) Relación del creador con el público que corresponde a las preguntas siete: 
¿Dónde pretende llevar a su/s receptor/ es?, y nueve: ¿Cree que el receptor completa su proceso de creación? Este epígrafe está subdividido en dos apartados: ¿Dónde pretende llevar a sus receptores? Y, papel del receptor en el proceso de creación.

Nos hemos limitado a mostrar y a organizar las respuestas de los artistas que expongan sus opiniones para encontrar las concomitancias y diferencias. Las conclusiones a las que hemos llegado finalizan el cuerpo del artículo, seguidas de los anexos con las respuestas de los entrevistados. $\mathrm{Y}$ finalmente, unas referencias bibliográficas ${ }^{2}$. La reseña biográfica de cada artista la hemos incluido como nota a pie de página junto al nombre de cada uno.

Para facilitar la lectura y evitar repeticiones farragosas, nos referiremos a los participantes con las iniciales de su nombre: Pilar Álvarez P.A., Llorenç Barber LL.B., Violeta Barrientos V.B., Inmaculada Cárdenas I.C., Augusto García Flores A.G.F., Xoán-Xil López, X-X.L., Fátima Miranda F.M., Jesús Otero-Yglesias J.O-Y., Monserrat Palacios M.P., Ana María Rocha A.M.R., Olga Verme O.V., y José Villalba J.V.

\section{DESARROLLO}

"De todos los misterios del universo, ninguno más profundo que el de la creación" Stefan Zweig (2010, Sinopsis, párr. 1)

\section{La obra de arte como creación}

Este trabajo comienza con una reflexión sobre el eje crucial de la actividad artística. La creación sintetiza a la vez un proceso y su resultado: el objeto artístico. Como fruto de ese proceso que le da vida y la acompaña, la obra de arte está provista de un fuerte componente dinámico que la define como el acto fundamental del artista. El acto de creación es el hecho esencial que determina su producto: la obra de arte como tal.

I.C. Sitúa en planos paralelos la creación artística y la creación divina. La obra de arte desde el inicio de la humanidad, la entiende ella, como una actividad vinculada a la religión y a la magia. Este pensamiento forma parte de su hacer creativo y ha tenido repercusiones en su concepto del arte como veremos:

Crear es el único verbo que empleamos al hablar para referirnos a Dios y para el trabajo que realizan los artistas. Crear es sacar algo de la nada, de donde no hay. Es curioso cómo la religión, el invento más completo del hombre, para explicar lo que no tiene explicación, estuviera unida en los orígenes del hombre a la magia y al arte. El mago era a la vez el que tenía los secretos de lo no visible, y para demostrar su poder utilizaba la magia. Cuando las culturas se hicieron más complejas, la magia se desdobló en religión y arte. De esta forma, la historia del hombre ha transitado siglos de prehistoria e historia. El hombre era la encarnación de Dios. Dice la Biblia 'hecho a su imagen y semejanza'. Esta visión homocéntrica del universo en la que

2. La bibliografía incluida al final del artículo es un conjunto de obras que pueden interesar a las personas que se adentren en el tema de la creación artística, pero no constituye un marco teórico del texto. 
el hombre es la criatura privilegiada y todo lo demás está a su servicio, va a cambiar en el siglo XX. La visión romántica del mundo va a cambiar por completo. Los descubrimientos de la ciencia -el otro pilar en el que se asienta la humanidad- van a ayudar a ese cambio de mentalidad".

Esta vuelta hacia atrás, a lo primigenio, es utilizada por la compositora para situar su concepción de la creación:

En el siglo XX, muchos artistas, pensadores y científicos ven al hombre integrado en el mundo. Estas premisas las comento para decir que la creación para mí, como para algunos artistas actuales es un proceso que vuelve la mirada al origen. François Baylle, músico electroacústico continuador de la obra de Pierre Schaeffer en el GRM de París, decía en uno de sus escritos 'la obra me encuentra' y efectivamente, esa era mi percepción de lo que pasaba en mis procesos de creación antes de leer a Baylle. En mi caso, hay una parte que denomino mágica y que es sorprendente.

Cuando comienzas con la idea de hacer una obra, tienes el tema genérico que puede ir cambiando y a partir de aquí como de un hilo de una madeja progresivamente todo se va abriendo. Decía Llorenç Barber: “...la música está ahí, sólo hay que escucharla y cogerla.

P.A., remitiéndose al Diccionario de la Real Academia, afirma que la creación es: "dar existencia a una cosa a partir de la nada". Próxima de alguna manera a esta idea, V.B. percibe la obra de arte como algo nuevo, cualidad a la que añade el carácter de necesario: El emerger de la obra artística, responde a "...un impulso y a veces llega a ser una necesidad. La necesidad de expresión interna, también el placer de que algo nuevo exista...".

A.M.R. nos reafirma el valor distintivo de la creación artística, ese valor que adquiere por sí misma: "No existe la creación absoluta; siempre alguien (sea individual o como conjunto social) ya antes se planteó de algún modo una intención semejante; por ello el resultado obtenido podrá tener coincidencias con otros, pero siempre será de alguna manera distinto".

La creación es percibida por M.P. como algo que se encuentra en lo profundo del ser a la espera del momento propicio para aflorar:

"Es entrar en uno mismo para encontrar lo que no se sabía que estaba ahí dentro y que siempre ha sido parte de uno mismo, siempre nuevo, siempre cambiante, siempre en continua construcción, pero dentro, aguardando el momento de ser atendido, ser escuchado".

LL.B. ratifica que la creación es aquello que aguarda dentro de nosotros y emerge como un descubrimiento gracias a una iluminación:

Crear es percibir una cierta iluminación mediante la que algo nace y crece en nosotros capaz de sugerir, producir, conceptualizar, argumentar y mostrar un algo más o menos inquietante $\mathrm{e}$ incierto que puede cambiar/mejorar/ discernir en algo nuestro entender/ disfrutar o el de otros que tengan acceso a ello. 
Este contenido que saca de sí el artista es para A.G.F el resultado de "un acto natural $\mathrm{y}$ volitivo en el ser humano en tanto que se dé una característica, o una serie de condiciones y facultades imprescindibles para que den lugar al acto creativo".

Sin embargo, no se trata solo de uno o varios momentos en los que el creador se limita a dar vida a su obra. Es un hecho vital y determinante para su existencia como persona y como artista, según nos subraya J.O-Y.:

Tanto el proceso como el acto de la creación son de una gran importancia en mi vida. No solamente por su repercusión en el trabajo que ejerzo, sino como componente de una forma de ser y estar en el mundo. La creatividad es, además de una herramienta para desarrollos estéticos, una forma eficaz, a menudo hermosa y sorprendente de solucionar problemas y conflictos, de hacer más vivo lo cotidiano y más ricas las relaciones sociales.

Por otro lado, nos manifiesta cómo con el paso del tiempo ha cambiado de significado su concepto acerca de la creación:

En un principio, tenía un claro matiz hedonista. El placer derivado de poner en marcha la creación resulta muy atractivo y deriva en momentos de gran concentración y, recientemente, con un fuerte componente de autorrealización. Con el paso de los años, y aun manteniendo este hedonismo, ha ido emergiendo una mayor conciencia de la responsabilidad que la creación implica.

F.M. señala que la creación constituye un proceso que se extiende a lo largo de toda una vida, de manera que sus obras, aunque llegan a su culminación en el escenario, representan para ella, una parte, momentos que forman parte de un todo que es ese transcurso vital:

El proceso de creación es muy largo y amplio y se extiende a lo largo de toda una vida aunque las obras que vayan construyéndose o ejecutándose sean diferentes, así que al final, cada obra viene a ser el registro de una parte de un proceso vital que culmina, en mi caso en el escenario, en una especie de ritual o acto de maravillosa soledad elegida para la que uno se ha venido preparando durante un largo período para llegar a la máxima perfección. De tal manera que, una obra, aunque ya esté compuesta, a la hora de ponerla en el escenario se convierta en un aquí y ahora único con una fuerza y una energía especial que es la que corresponde a ese momento que no puede constar en partitura, no puede constar en la composición de la obra.

Pero el arte es también, añade, poética en el sentido de construcción, noción que encierra el término griego correspondiente. Este concepto, que comparten algunos científicos, es el que, en sus palabras, da sentido a la obra de arte, que requiere, tanto de lo poético, como de lo conceptual. Además, el artista como creador no puede eludir su propia preparación intelectual, el cultivo y agudización de la percepción, el entrenamiento físico en algunos dominios artísticos, para contribuir al desarrollo de la sustancia poética de su obra:

El arte es poética, poesía, sí, también, pero poética. Poiētiké en griego es construcción, hay un componente de 
construcción. Vivimos tiempos de mucho mecanicismo y donde la gente depende más del azar, de una maquinita de video, un MP3 o cualquier ordenador que todo el mundo lleva metido en el bolso, o en un teléfono móvil, que dé una formación o dé un entrenamiento de la percepción del propio artista, sea física, en el caso de los bailarines o de los cantantes, o sea intelectual. Uno puede tener ya un alcance poético en su vida, pero todo esto se nutre y va evolucionando y así va creciendo el componente poético de la obra. Creo que lo tiene, también la obra de algunos científicos, no hay más que leer a Ramón y Cajal y a Einstein...”.

La creadora denuncia ese falso arte de quienes, sin nutrientes ni preparación, producen obras sin nivel poético ni conceptual:

...es cierto que hay miles de personas que se consideran, o que se creen artistas, en las que su obra tiene que ver con algo mucho más mecanicista que poético, y hay obras cada vez más carentes de alcance poético y de nivel conceptual. Es decir, es como comemos, crecemos, nos nutrimos, pues, también depende de la nutrición de nuestra vitalidad. Si somos curiosos, y salimos y si entramos y miramos la obra de otros, si leemos y guardamos silencios y hacemos alguna práctica interior que nos ponga en situación de entrenamiento neuronal, esto podía también formar parte de los procesos y al final, todo se relaciona con todo. Insisto, hay muchos artistas que no son tales en absoluto y que se autodenominan así. Bueno, cada uno se conforma con lo que quiere, se consuela con lo que puede, pero a veces no hay ni un atisbo de carácter poético, ni conceptual, y la obra tiene que estar respaldada por la idea o por ese alcance poético, si no, no es arte...

J.V. nos presenta la creación artística como motor y estímulo del desarrollo, así como de la mejora de la sociedad y la búsqueda de la belleza: “...la espita a través de la que ese patrimonio excepcional de los humanos -que es el ingenio- fructifica en la búsqueda del bienestar, a través de un desarrollo intelectual no pocas veces asociado a la aprehensión de la belleza en su sentido más profundo".

Ex nihilo nihil fit

Nada surge de la nada Frase atribuida a Parménides

Pero la creación artística no es evidentemente el fruto de la nada, detrás de cada creador hay un acervo que aporta como individuo y como sujeto cultural y social. Es el peso de la tradición, que nos sirve de referente para reafirmarnos en ella, para buscar un camino diferente o para romperla.

Nos dice P.A. "...sin memoria, sin atender a los pasos seguidos por los que nos precedieron, es imposible que esa creación se pueda realizar". A.M.R. emplea la metáfora del tejido para referirse a ese bagaje que todo creador trae tras de sí, al que se une su aporte personal:

Una buena metáfora de lo anterior es la del tejido: la urdimbre sería todos aquellos aspectos de la creación que escapan al yo creador y que es la 'base' para la creación individual (contexto social, cultural e histórico, experiencias 
y obras realizados por otros, etc.). La trama es lo que vamos construyendo con nuestra intención, y allí se filtra nuestra vida, gustos y experiencias personales. La primera -urdimbre- es el soporte no individual de la creación, nos proporciona los insumos generales que van formando y determinando la trama que construiremos. Pero, es el creador el que construye la trama y el resultado final, lo que alcancemos y definamos como 'nuestra' creación.

Pero el vínculo del creador con la sociedad y su entorno cultural no se reduce a la herencia recibida, de la cual, indudablemente, se beneficia. Digamos que el artista no solo busca hacia atrás, enfocando ese legado, sino también mira desde su "aquí-ahora" hacia la sociedad. La creación artística nos puede ofrecer "una mirada sobre la realidad" como nos señala O.V.: Una mirada que queda reflejada no solo en la retina del artista, sino que constituye una cierta apropiación de esa realidad pasada por el tamiz de su trabajo creativo, que nos proporcionará como resultado su obra.

Para X.X.L. la labor creativa supone: "En primera instancia un proceso de aprendizaje que finalmente se transforma en un trabajo artístico que busca explicar/contar algo o generar algún tipo de emoción”. El resultado de este recorrido es para este creador: "...una forma de relacionarme con el mundo, de conocerlo". V.B. va más allá, cuando señala que al aportar algo nuevo, la creación: “...cambia el mundo de alguna manera".

Las relaciones de los artistas con la sociedad pueden también responder, nos afirma J.O-Y. a las expectativas que tiene la propia sociedad para con ellos. Respuestas con las que el creador pretende ayudar a un mejor conocimiento de su entorno, en un movimiento dialéctico de intercambio e interpretación entre el sujeto/creador y la sociedad:

Creo que la sociedad espera diferentes cosas del creador, algunas opuestas entre sí. En cualquier caso, es de la mayor importancia que su trabajo contribuya a hacer más comprensible y aceptable el mundo, que puede quedar fácilmente opacado bajo las capas de información e inconsciencia que nos rodean, alienando la consciencia y el pensamiento.

Para este artista "La creación... tiene cada vez más el carácter de oposición, o, si se quiere, de resistencia ante la cultura hegemónica, una forma de contracultura necesaria".

\section{La relación del artista con su obra}

\section{Los momentos del proceso creativo}

El proceso creativo nos lleva a desarrollar una mirada dinámica en la que el creador intenta presentarnos la manera cómo percibe el desarrollo de su quehacer artístico. Son los diferentes momentos en los que se desenvuelve el proceso creativo.

A.G.F. no ve con claridad momentos necesariamente diferenciables en el desarrollo del proceso creativo. "... no creo que siempre sea igual, ni siquiera, en la misma persona" nos dice.

LL.B. lo percibe como un proceso variable en el que se puede desarrollar etapas, más o menos largas, o prescindir absolutamente de ellas: 
Veces hay que sí, pues las percepciones pueden darse en pequeñas diócesis, tragos, saltos y acercamientos que mejoran, complementan y completan ese iluminador atisbo inicial, y veces hay, por contra, en que todo se da de un solo soplo, como Paulo cayendo súbitamente del caballo.

O.V. distingue entre la reflexión y la realización de la obra. A estos dos momentos añade el factor tiempo que actuará como un elemento decisivo en el proceso de maduración de la creación: “... la reflexión, la realización, su evolución, el tiempo en función de los sentimientos y lo vivido".

P.A. nos señala la necesidad de una labor predecesora al trabajo creativo: “... cualquier estilo literario del que hablemos precisa de un trabajo previo, investigación, recopilación de datos, experiencias previas, etc., y a partir de ahí comienza el verdadero acto de creación."

\section{I.C. diferencia cuatro momentos:}

El primero sería saber qué obra quieres hacer. En mi caso, ha podido ir desde obras electroacústicas, hasta obras experimentales, improvisadas, pasando por obras audiovisuales, intervenciones sonoras, etc.

En un segundo momento, es fundamental determinar el material con el que se va a trabajar:

...que puede ir desde objetos cotidianos -he realizado obras con muchos objetos y muebles de mi casa, cerámicas, etc.- hasta todo tipo de instrumentos clásicos, populares y étnicos o inventados y construidos para la obra, como hicimos en Concierto para Esculturas Sonoras y en la ópera Serea e o Contador de Contos. El material con el que se trabaja es importante porque sus sonoridades van a orientar y definir la obra".

En el tercer momento, se desarrolla el trabajo sobre el material sonoro previamente seleccionado y preparado:

El tercer momento es cuando ya tienes el material sonoro (temas o materias sonoras en el caso de la música electroacústica, generadas con la manipulación, en laboratorio, de grabaciones reales). A partir de aquí puedes comenzar a elaborar un primer boceto de obra, que puedes cambiar a lo largo del proceso. Estamos hablando de la estructura de la obra.

En cuarto lugar “...está el ajuste de detalles para darle unidad y redondez a la misma".

A.M.R. enfoca el proceso creativo en tres momentos: "Generalmente, tenemos un primer momento de ideación o germinación de una intención, otro de investigación y desarrollo hasta que, finalmente, el cierre del proceso implica un resultado."

En el desarrollo de este proceso, nos recuerda, que hay que tener en cuenta ciertas variables:

Que la germinación: "no es muchas veces instantánea, sino producto de otros conceptos o ideas que han sido descartados o remodelados". Que: "El concepto inicial siempre se va transformando durante el proceso mismo". Que: "el ritmo del proceso puede variar". Que: 
"la secuencia de este proceso no tiene un desarrollo necesariamente lineal...y cada 'momento', es en sí un pequeño proceso donde la linealidad se rompe y aparecen círculos o líneas paralelas". Que: "Frente a la búsqueda de concretización de una obra, hay muchas opciones que influyen (desde la técnica elegida...hasta nuevas experiencias, percepciones o ideas que encontramos en el camino)”. Y, que: “...el resultado final muchas veces es distinto a lo pensado inicialmente..."

V.B. hace depender las etapas del proceso creativo de la dimensión y complejidad de la obra, al igual que el "momento de investigación y de reunir materiales". En cuanto al impulso inicial, reconoce que puede llegar, con más o menos facilidad o, en otras circunstancias, el artista requiere cargarse de energía, prepararse o auto estimularse creativamente: “...es necesaria una autoinducción...".

M.P. diferencia entre creación y acto creativo. El acto creativo es en sus palabras: "...la toma de consciencia de un momento preciso de la creación en el que deseo detenerme, dar forma, construir algo 'materializable'. A ese momento que intento aprehender, se le suele llamar 'idea"'.

Luego de entrar en contacto con esta idea, manipularla, darle forma, escucharla, etc. la misma se transmuta convirtiéndose en algo que nos asombra. M.P. nos sigue diciendo:

...se transforma en algo, que ya no es totalmente lo que imaginábamos que sería; la creación siempre sorprende al acto creativo, el resultado no es más que música de la experiencia $\mathrm{y}$ acto puesto en relación, momentos diferenciables de un proceso nunca terminado porque es la oreja del otro quien continuará dando forma al acto, como vasos comunicantes más que como un jarrón de agua estancada.

J.V. hace intervenir el azar en el desenvolvimiento del proceso creativo. Distingue entre la idea inicial y su desarrollo material. Idea que dará inicio al proceso:

...se accede a partir de una casuística muy variada, en la que con frecuencia interviene la casualidad; pero el desarrollo de esa idea exige, en casi todos los casos, un amplio bagaje técnico e intelectivo, parejo a las mismísimas facultades creativas, para que el proyecto solidifique con éxito.

X-X.L. afirma que en un primer momento: “...una obra o proyecto suele surgir de un interés por algo concreto: un sonido, un acontecimiento, una sensación. Pero al principio suelen ser ideas muy difusas que luego intento formalizar profundizando algo más en su esencia”, para en un segundo momento "darles forma a través de una construcción artística utilizando diferentes técnicas o formas de representación: instalación sonora, composición, texto, performance, etc.”.

Para J.O-Y., el proceso de creación pone en funcionamiento diversos niveles de actividad cerebral:

... La creación parece ser un proceso que ponga en marcha diferentes niveles del funcionamiento cerebral. Niveles que tendrían que ver con la primera tópica freudiana: subconsciente, preconsciente y consciente. En 
el proceso de buscar una idea, de darle origen o forma, los primeros momentos, días, incluso meses, parecen estar dominados por una cierta confusión y círculos viciosos en los que no parece fácil evitar lo evidente, las facilidades ya adquiridas y conocidas. No cediendo a estos pobres avances, queriendo que acudan nueva ideas y asociaciones, puede ocurrir que vayan emergiendo nuevas y, a menudo, insospechadas soluciones o enfoques. Parece, en tal caso, que se haya dado un trabajo inconsciente que, algunas veces, es percibido bajo la sensación de que algo esté a punto de ocurrir, afín con la expresión 'tener algo en la punta de la lengua', pues, aunque no lo percibimos con claridad, si nos damos cuenta de la posibilidad cierta de recordarlo, como acaba ocurriendo tras un cierto tiempo. A mí me parece un proceso de conocimiento parecido. Creo que este trabajo subconsciente se favorece con una aceptación pasiva, en principio, de cualquier buena idea por irrealizable, ilógica, o extraña que parezca, y un proceso paralelo, aunque parezca contradictorio, de descarte, de decirse a uno mismo: ¡esto no es! ¡esto no es!, ¡esto tampoco! hasta que, finalmente, aparece la idea que se adecúa a lo que buscábamos o nos resulta satisfactoria. Así que hay procesos oscuros de los que no nos damos cuenta, aunque los podemos incentivar con la insistencia en la investigación de la idea y la búsqueda de nuevas fuentes de información y conocimiento. Estos procesos son seguidos por otros preconscientes en los que tenemos la percepción de que estamos a punto de encontrar algo, lo cual sostiene la confianza en un resultado final favorable. Finalmente, momentos de consciencia, o incluso de iluminación o revelación repentina, que pueden aparecer sin el paso previo de la percepción preconsciente, en los que se pasa de la obscuridad a la luz, por así decirlo, de un modo bastante repentino".

Este artista señala también la conexión en la creación entre las sensaciones físicas que acompañan su proceso y la mente:

El proceso de creación como de emergencia desde niveles difusos a otros de mayor claridad puede estar acompañado también de sensaciones físicas, al punto de no pocas veces saber que hemos llegado a una buena idea o solución cuando el momento va acompañado de una percepción física de bienestar o de paz, que con el tiempo se vuelve reconocible y seña de progreso en el proceso creativo. El cuerpo parece, por tanto, tan importante en el proceso de creación como la mente.

F.M. reconoce cuatro fases en su trabajo creativo. El germen inicial puede ser anterior al trabajo compositivo propiamente dicho y haber quedado reservado en la memoria o archivado por algún soporte para su posterior utilización:

...A veces una idea que va a ser el germen de una obra tiene origen en un momento lejano y depende del método de trabajo de cada cual; pero, como yo las ideas las suelo archivar por medio de un registro sonoro o, por medio de notas, sucede que no abordo la creación de la obra en ese momento, sino que tengo fases en que me dedico 
a un trabajo vocal estrictamente de perfeccionamiento, de investigación de técnicas vocales $y$, otros momentos en que me concentro en el trabajo compositivo.

Una segunda fase está constituida por la recuperación y reunión de dichas ideas:

Ese momento del trabajo compositivo es cuando reúno las ideas y me doy cuenta de que, a lo largo de una línea de tiempo largo, serán constantes. Entonces voy asociando estas constantes para dar estructura y forma a la obra. Ese sería el segundo momento después del germen inicial.

Hay un tercer momento cuando dentro del proceso de creación, en mi caso, al haber un trabajo extremo vocal, pues una cosa es la melodía o la idea y otra cosa es aquello que es posible y cuando lo pasas por el cuerpo, el cuerpo te trae respuestas, te trae nuevas ideas y el germen inicial se convierte en, no en otra cosa, sino que efectivamente es como un inicio, lo que se tenía luego se va construyendo a medida que se va haciendo.

Finalmente, la última fase:

Después de una búsqueda y un ajuste de lo que son los recursos vocales, de lo que se quiere transmitir con esa composición, se llega a la composición propiamente. Aquí, se pasa a otra fase que es la de cantar y que es cuando el gesto te lleva a imaginar: una luz, un cierto color, un cierto vestuario, o un cierto recorrido. La parte gestual es muy importante, y la estática, gestual en cualquier caso, culmina en el escenario.
Termina analizando el papel que juega la técnica en la creación artística. Es crucial para el artista trabajarla, utilizarla, pero, sobre todo, saber despojarse de ella, para que del trabajo de preparación la obra de arte aflore:

Es muy importante, pero también es una fase, es decir es como comemos, crecemos, nos nutrimos, pues también depende de la nutrición de nuestra vitalidad. Si somos curiosos $\mathrm{y}$ salimos, y si entramos y miramos la obra de otros, si leemos y guardamos silencios y hacemos alguna práctica interior que nos ponga en situación de entrenamiento neuronal, esto podía también formar parte de los procesos. Al final todo se relaciona con todo. Y es, cuando la obra se libera de la técnica, cuando aparece. Pero, hay gente que no trabaja la técnica, luego no puede olvidar lo que no ha trabajado. Para la obra es fundamental (liberarse de la técnica) que el resultado emerja del olvido de todo, de todo lo que uno tenía planteado; aunque la obra haya llevado un proceso desde una idea que se tuvo, una técnica que manejar, unos instrumentos, unos elementos, unas herramientas. Lo cierto es que, al final de pura repetición y entrenamiento y revisión, emerge algo más que es como una crema, algo muy sutil. Y, cuando tienes que presentarla en escena, más aún, el arte tiene que estar desprovisto completamente de técnica; bueno, no debe notarse, tiene que estar dentro de la esencia de la semilla, pero no debe notarse. La técnica es un aspecto fundamental, no es una etapa, porque es algo que se nota continuamente. Es fundamental en todo proceso de creación y hay que estarla cultivando 
hasta que uno se muere para que la obra justamente sea inmortal. Esto es algo trabajoso, tiene un componente de sacrificio, pero, no tanto como se entiende en la tradición cristiana de sufrir, sino de acto sagrado, sacrificio de un acto sagrado, de crecimiento personal. Y la repetición siempre te da entrenamiento, es lo que convierte a la obra en algo único, en uno mismo, es decir en la obra de un autor determinado por su sello".

\section{Condiciones para poner en práctica el proceso creativo}

LL.B. nos dice:

Unas veces, las más, estar en un cierto 'tono' de percepción, soledad, calentamiento de mientes e intuiciones en torno a algo que nos es problema a discernir, es base desde la que incubar algo es lo más natural. Otras veces, ese 'tono' no se da, pero se dio, se buscó, se intuyó, sin llegar a adivinar o percibir esa luz postulada o buscada con ahínco; $\mathrm{y}$ de repente estando aparentemente en distracciones, algo se ilumina, y se nos da como un regalo, una fruta madurada, entera y ya caliente para ser degustada y aparentemente sin esfuerzo alguno.

Para A.G.F., es necesario partir de una condición previa imprescindible: "saber qué se quiere expresar...”.

Posteriormente, la realización requiere poner en práctica una serie de elementos con los que se buscará, en la medida de lo posible, acercarse a la idea inicial que suscitó el acto de creación: "Luego viene un recurrir al conocimiento o a la experiencia personal, trasladarlo o componerlo a modo para que se identifique lo más posible con la idea, o el ideal, que ha movido todo; quizás sea mejor decir: removido".

I.C. y M.P. no ven necesario ningún requisito en especial para poner en práctica este proceso. Se refieren al entorno circundante, pues, para ambas, la creación puede surgir en cualquier momento, o en cualquier circunstancia. Sin embargo, las dos artistas matizan en cuanto al desarrollo del proceso creativo, en el que sí reconocen, que necesitan ciertas condiciones.

M.P.:

...el proceso creativo ocurre a veces sin ser yo consciente de ello, podría crear con cualquier elemento y en cualquier circunstancia. Es la idea, la imaginación que me asalta, de pronto, sin importar dónde me encuentre... Pero, esas serían condiciones materiales para dar forma a la obra más que al proceso. $\mathrm{Si}$ pienso en el proceso en sí, en mi caso sólo requiero imaginación y escucha.

I.C. nos dice al respecto: "Ninguna en especial. Se me pueden ocurrir, desde las ideas a los temas, en los sitios más diversos, paseando, en una cafetería. Pero, cuando estoy trabajando en la obra, ahí si requiero del silencio y la tranquilidad para concentrarme". O.V. requiere también sosiego: "La tranquilidad para mirarse a sí misma y al mundo exterior".

A.M.R. comparte esta necesidad unida a otras motivaciones internas y externas:

Las condiciones van desde lo psicológico y espiritual (motivación interna profunda, entusiasmo por una idea o concepto a explorar, tranquilidad, distanciamiento de los otros) hasta lo económico (desligarse 
de los problemas de ese tipo, no pensar en el día a día).

Esta seguridad económica a la que se refiere A.M.R. es también un requerimiento de P.A., que alude a la escritora inglesa Virginia Woolf: "Decía Virginia Woolf que toda mujer para ser creadora necesitaba una habitación propia y 500 libras de renta anual, porque sólo la libertad permite la creación; hoy sigue siendo válida esa afirmación".

V.B. reclama también la necesidad de contar con un espacio físico para poder crear. A este condicionante le suma la necesidad de contar con el tiempo que esta tarea necesita. Para esta escritora, la búsqueda de referentes es, igualmente, una circunstancia significativa para desarrollar un trabajo creativo, aunque se muestra versátil respecto a su comodidad personal, que no considera un requisito imprescindible para su trabajo: "Espacio físico, temporal y referentes (ver qué está hecho y qué se podría hacer). A veces se crea en condiciones más confortables y otras en condiciones de guerra. Ambas son estimulantes". J.V. afirma con rotundidad: "El tiempo y la motivación", coincidiendo con ella en el factor temporal, al igual que con A.M.R.

J.O-Y. enumera tres condiciones de orden espacial:

- Interés por el espacio: "Tiene que interesarme el espacio donde se instalará la obra, he de encontrar un punto de interés o motivación que tenga que ver con el espacio en sí mismo. Cada vez es más importante para mí que haya posibilidades de intervención, que puedan ser diferentes y/o de crear itinerarios, o maneras de encontrarse con la obra, para el receptor o visitante de la muestra, que le resulten menos usuales. El espacio moldea la conciencia del receptor: eso ya es un fin en sí mismo".

- Las características formales del edificio: "Presto mucha atención a la forma del edificio donde tendrá lugar la intervención, a veces simplemente las sugerencias formales de éste pueden desencadenar un proceso creador con un buen resultado".

- Las connotaciones que el espacio elegido le pueda proporcionar: "Otra condición es que haya una historia, un sedimento narrativo al que recurrir, o que desde las condiciones o situación del lugar, pueda iniciarse algún desarrollo que conecte con las ideas con las que trabajo habitualmente".

X-X.L. nos habla de la necesidad de cierta inactividad inicial como requerimiento para la creación, un saber librarse de ocupaciones del entorno cotidiano: "Creo que hay que vaciarse para ofrecer espacio al azar, al tedio, etc., a todas esas cosas que intentamos desterrar de nuestra vida por considerarlas improductivas". Esa tranquilidad mental termina siendo el inicio en el que el artista germina una obra.

Esta idea de vaciarse de lo adquirido la encontramos también en F.M. que, además, nos habla del necesario estado de alerta del creador, el entrenamiento y su formación constante, señalando los requerimientos del trabajo con la voz (como es su caso), un instrumento para cuyo ejercicio, lo físico, su propio cuerpo es esencial:

Es algo contradictorio. Por una parte, has de estar bien nutrido, has de nutrirte, has de vivir en un compromiso 
de entrenamiento constante y de atención... Del proceso creativo forma parte la vida entera... Por su parte, cuando se trabaja con la voz, hay una parte interior muy importante porque la voz es afuera y es adentro. Es cuerpo es fisicidad pura, más de doscientos músculos intervienen, pero a veces es aire; no se puede ver, no se puede tocar y no tiene un instrumento con herramientas externas, como para saber dónde hay que dar, tocar; no se tiene en cuenta con la tensión de una cuerda un clavijero, una caja de resonancia externa al cuerpo. Hay casos de compositores que componen para otros; en mi caso, lo hago para mí misma, y el entrenamiento es de importancia capital. Hay que estar alerta también para cuando te viene la idea.

Pero, por otro lado, está ese concepto de vaciarse como condición sine qua non antes del acto creativo, para que la búsqueda se concentre en lo esencial y lo propicie:

...se tiene que producir un vacío; para que algo se llene, tiene que estar disponible y a veces estamos llenos de demasiados estímulos, de demasiada información, de demasiado querer decir algo; y a veces es del abandono de donde emergen grandes ideas y grandes obras. Siempre y cuando a esa intuición que acontece en momentos de abandono se le una un trabajo sistemático. La intuición sin un trabajo sistemático es completamente estéril y no sirve a nada.

\section{El modus operandi}

P.A. manifiesta repetir una manera definida de trabajar. Repite la misma rutina: escribir de noche y corregir de día. "Podría decirse que hay un modo de trabajo que se repite en todas mis obras, escribo de noche y corrijo o desecho a la mañana".

M.P. afirma que tiene un modo concreto de hacerlo. Este comienza con la definición de las ideas: "...que empieza por la concreción... y su forma en el espacio. Mi trabajo suele ser siempre muy intuitivo y también muy performático. Así que pienso en ciertos trayectos, movimientos y elementos en el espacio, situación del público, etc." Para concretarlo en una partitura visual que le sirve como herramienta de trabajo y que tiene relación con un trabajo escénico o coreográfico, a la que incorpora la acción sonora que se propone desarrollar:

...por lo que casi siempre me facilita hacer una partitura visual en papel, de mis movimientos, de los elementos que vaya a utilizar para determinada obra (tierra, plumas, copas de cristal, teteras, máquina de coser, etc.), y de la acción sonora con estos elementos, como imágenes acústicas. La partitura sólo me funciona como una estructura general muy abierta...; me gusta trabajar con símbolos, donde cada elemento tiene una importancia específica; suelo documentarme teóricamente sobre algunos aspectos que quiero trabajar y cuando todo acaba escribir sobre ello.

Otros artistas consideran que su labor varía según la obra que pretenden realizar. Ese es el caso de V.B., quien afirma que su modo de trabajo, siendo esencialmente el mismo, varía según la obra: "Por lo general es el mismo en cuanto a etapas. Luego claro que cambia, según el contenido de la 
obra". A.G.F. dice "Sí que varía, nunca hay nada igual, aunque muy semejante, eso sí. Pero nunca se sabe cómo ha de venir, ni resultar. Creo que las teorías que hay sobre la 'inspiración' son metáforas que pueden ayudarnos a definir todo este proceso, incluso las más lamentables". O.V. afirma repetir el mismo esquema de trabajo con las correspondientes variaciones que le impone cada técnica de grabado: "Siempre es el mismo y en grabado cada técnica tiene un proceso creador diferente".

LL.B. apunta a la mutabilidad que puede encerrar la creación, que se perfila como una pesquisa que se va desvelando a veces con dificultad:

Crear es, las más de las veces, algo bien 'caprichosón' que tiene su propio querer, sus propios modos, planos, maneras de desvelarse, etc.; lo que un día vale, no lo valdrá el siguiente. Con todo, el estar en estado de vigilia/ búsqueda/desembrolle, etc. lo es todo. 'No te buscaría', decía Agustín de Hipona, 'si no te hubiera encontrado'.

A.M.R. también apunta al carácter variable de la actividad creativa. Un primer momento, en el que es conveniente dejar fluir la vena creadora; luego, es importante dejar pasar un espacio de tiempo, que permitirá variar la perspectiva del creador y actuar como un corrector de lo realizado:

Creo que todo esto también es variable. A veces cuando uno cree/siente que está 'como inspirada' es mejor escribir o dibujar casi mecánicamente. Luego, es recomendable dejar pasar un tiempo y corregir. Creo que el tiempo es un buen corrector, en el sentido que permite distanciarse de la obra en proceso, verla con otros ojos. ¡Con otros ojos!
Pues, algo de uno se ha transformado en ese tiempo.

Para J.V., las obras tienen diferentes requerimientos que diversifican los procedimientos del artista. $\mathrm{Su}$ punto de partida es:

...una imagen fugaz que me proporciona el azar... El análisis de ese desencadenante despeja las claves de la percepción inicial y, a partir de ahí, arranca el hermoso decurso de darle carne a las ideas y de elaborar una estructura que le aporte coherencia/ consistencia al producto.

Una vez que las primeras ideas toman forma, es la materialización la que guía al escritor a continuar su trabajo creativo:

Cuando esas ideas ya han cobrado vida propia y se adaptan con naturalidad a las estructuras prefijadas, los pasos siguientes resultan aún más satisfactorios, porque son los mismos elementos/agentes los que guían... En mi caso, los personajes de las historias, que aconsejan al autor a modificar si es preciso las estructuras inicialmente trazadas... En el ámbito de la creación literaria, hablo de ese momento mágico en que los personajes empiezan a tomar decisiones por sí mismos: se han convertido en entes tan palpitantes que hasta asesoran al autor en la tarea de plasmar coherentemente sus actos $\mathrm{y}$ decisiones. Si los personajes son potentes, el autor tiene mucho que aprender de ellos mientras trabaja. Es un moldeo mutuo.

I.C. habla sobre su método de trabajo: 
Varía según la obra, ya que hacer una obra electroacústica es muy diferente, en su proceso, que realizar una obra improvisada para instrumentos, o una intervención sonora. Por otra parte, cuando trabajas en solitario las reglas que en el arte siempre las pone el autoreres tú quien las controlas. Si trabajas tú solo, vas eligiendo estos recursos, $\mathrm{y}$ vas desgranando las entradas y los temas.

Muchas de mis obras, son obras cerradas desde su finalización y se conservan en un soporte, de manera que son un objeto material, como un cuadro. Por ello, entiendo que se pueden presentar tanto en concierto como en exposiciones, como la exposición de los Sons Creativos ${ }^{3} 25$ Anos de Pedagogía e Arte Sonora en Lugo, en el MIHL (Museo Interactivo da Historia de Lugo). Todo cambia cuando trabajas en un proceso de creación en grupo. Hay que explicar qué quieres y ponerse de acuerdo. En mi caso, la improvisación forma parte de mi manera de componer. Por tanto, si los músicos no tienen un nivel de improvisación adquirido, entra en acción mi faceta pedagoga".

X-X.L. piensa que repite algunos procesos. Afirma que su punto de partida suele ser sutil y, posteriormente, adecúa su manera de trabajar a la obra que se propone realizar:

Aunque estoy seguro de que tengo algunos procesos de los que no soy consciente del todo, ya que no soy muy analítico, o introspectivo, a este nivel, por lo general, cada obra parte de algo sutil y para poder desarrollarlo suelo adaptar el proceso a la obra que quiero formalizar.

J.O-Y. distingue entre dos tipos de proceso en su trabajo creativo. Por un lado, los que tendrán una resolución espacial y están dirigidos a utilizar una arquitectura y los que estarán configurados en un formato específico y no se encuentran condicionados por el espacio. En el primer caso, incluye las instalaciones e intervenciones, y en el segundo caso incluye: dibujos, pinturas, textos, vídeos, etc. El artista nos aclara la importancia que tiene para él el conocimiento del espacio:

Igualmente me es necesario un conocimiento del lugar donde se va a desarrollar ese proceso creativo o su consecuencia. Es siempre preferible el conocimiento in situ del espacio. Para mí resulta cada vez más importante que el trabajo sea adecuado al lugar, actúe sobre él y éste no sea un mero continente de aquello que se hace en el estudio. En el caso de una instalación puede incluso ocurrir que no aporte ningún material y trabaje con lo que me encuentre en el espacio a intervenir o en sus inmediaciones. La obra debe activar el espacio y el espacio determinar el efecto de la obra. Un diálogo y una coordinación entre ambos son vitales para que el resultado no sea fallido. Lo que intento es 'sorprender al espacio', en el sentido de que este suele estar acomodado a unos usos, que no siempre son los que mejor resultado obtienen de sus posibilidades.

3. Los Sons Creativos son un foro anual de conciertos de divulgación del Arte Sonoro y la Música Electroacústica que se celebran en Lugo, organizados por El Grupo de Creación Sonora de la USC. Dirigidos por Inmaculada Cárdenas y Xoán Xil López. 
Otro elemento de gran importancia para este artista es el tiempo:

Cada vez doy mayor importancia al paso del tiempo como factor de maduración de la idea. Los casos en que no hay plazos concretos de entrega o me puedo permitir tomarme todo el tiempo que quiera, son los que prefiero. Me permiten distanciarme de los recursos que ya conozco enriqueciendo mis posibilidades futuras. Podría recordar ahora la expresión de Joan Miró cuando afirmaba trabajar como un jardinero, dejando que cada obra creciese y alcanzase su madurez, fertilizando aquí, podando allá, etc.

En este aspecto coincide con la valoración que A.M.R. hace de esta variable en el proceso de creación.

J.O-Y. también destaca, en el modo de desarrollar su trabajo, la manera de utilizar la anotación como método de conservación de las ideas que le van surgiendo:

En mi proceso es importante estar constantemente anotando, apuntando cualquier idea por insignificante que parezca. Tengo tres clases de blocs de anotaciones... en los que anoto cualquier idea que me venga a la mente o la idea básica de algún proyecto que tenga en marcha, a menudo apoyando el texto en imágenes y en los que trabajo generalmente por la noche. Cuando un proyecto o exposición es aprobada recurro a otra clase de bloc... Por último, tengo la costumbre de llevar conmigo pequeñas libretas, especialmente cuando preveo que vaya a tener momentos muertos o de espera en lo que, tengo comprobado, acuden buenas ideas.
A la pregunta de si tiene una manera definida de trabajar o esta varía según la obra, F.M. nos responde que: “...hay aspectos de la creación que son definidos y, a veces, la ejecución depende de cuestiones varias, desde dificultades de tipo vocal, hasta dominio de un pequeño instrumento que me pueda acompañar y que he de dominar". Cita un ejemplo:

De pronto el instrumento me cuenta cosas diferentes y entonces la obra evoluciona en función de lo que el instrumento te dice; me estoy refiriendo en particular a mi obra 'Entre Salamanca y Samarcanda' donde el bordón y los armónicos del instrumento iban tirando de mí: fonemas, palabras que yo no tenía previstas y que se fueron construyendo desde el registro en el que yo tenía que cantar, dependiendo de la cantidad de agua que había en el instrumento, y un registro te lleva a un tipo de fonema y otro te lleva a otro.

Para F.M., parecida es su relación con el vestuario que le lleva a modificaciones en la obra:

En Cantos robados estoy en un traje de tres metros de altura; el hecho de que yo me acompañe de juguetitos aparentemente insignificantes -esos juguetes tienen su tono, tienen su frecuencia- y el hecho de estar tan elevada y de estar subida sobre una falda de tres metros de altura, te lleva a un gesto y ese gesto te lleva también a ciertas emisiones vocales, etc. Es decir, que hay elementos que son fijos en el proceso y otros que son variables, casi más en función de elementos externos. A veces, la idea viene de 
algo que escuchas en la calle, desde un claxon, hasta el ruido de una puerta, o de un timbre o algo que encuentras en un anticuario y esto ya te da una serie armónica. Y otras veces, te viene de una emoción o de un acorde que te lo proporciona una máquina industrial, o de la nada, del silencio, del silencio dentro de ese 'vacío', dentro de esas fases de 'vaciado' que son tan importantes para el artista".

\section{Diferencias entre los procesos creativos en las diversas artes}

Dentro del dominio del arte, encontramos una serie de prácticas que con características formales y medios materiales distintos -en algunos casos transversales o intercambiables- comparten ese valor fundamental que define al arte.

Según A.G.F., no existen diferencias en los procesos creativos de las diferentes artes. I.C. piensa que no las hay en lo que a la creación se refiere, pero sí con relación a las técnicas y los materiales empleados. Sigue aclarando que:

A nivel de la creación, hay un impulso común entre las artes. Pero, cada arte en particular encamina sus técnicas por diferentes recorridos, que están ligados a los materiales con que trabajan: el sonido, el color, la materia sólida, la palabra, etc.

A este impulso, I.C. añade una fuente primigenia:

...Lo que sí creo es que hay un eje común entre las artes, que podríamos decir que es el gesto. Éste es evidente en la música, la pintura, la danza o en la arquitectura tradicional. En literatura estaría en la poesía, en el gesto vocal, el ritmo de las palabras, etc.

AM.R. sitúa las distinciones a nivel de las técnicas: "Hay ciertas diferencias por los medios y técnicas elegidos y ello determinará el resultado. Pero, en todos los casos, lo que hace la creación artística única es tratar de decir algo de una manera personal y diferente". Algunos casos ejemplifican esas diferencias:

La literatura, al usar la palabra, tiene como recurso un código que es el lenguaje verbal común a toda una comunidad. $\mathrm{Y}$ ese código de tan aparente inmediatez, tiene que liberarse justamente de lo 'común' para volverse distinto y novedoso y así seducir o impactar al receptor. He ahí lo complejo... En las artes visuales o plásticas nos encontramos frente a códigos secundarios, que hay que aprender de 'ex profeso' y tratar de manejar/dominar para alcanzar una técnica expresiva. La técnica determina los límites y alcances de la expresividad y comunicabilidad ejercidas por el creador en el proceso creativo. Por ejemplo, si no manejo el intaglio, no puedo hacer 'casi nada' a no ser que convierta ese 'casi nada' en algo expresivo, pero con límites marcados.

J.V. encuentra que existen diferencias: “... dentro de cada arte en general y cada artista en particular"; opinión que comparte M.P., quien, a pesar de reconocer puntos comunes entre las diferentes artes, encuentra que su carácter subjetivo es el factor que las condiciona:

No sólo en las diferentes artes, sino en los diferentes artistas de cada arte, el 
proceso creativo puede tener puntos comunes, ciertos anclajes, incluso obligados, para conseguir ciertas obras; pero aún así, el proceso creativo es muy subjetivo, y son esas sutilezas personales, esas intuiciones que nacen en una mente y no en otra, esos rasgos que se parecen pero que no son iguales, los que marcan el cambio, los caminos y los paradigmas.

P.A. ve diferencias en los procesos creativos de las diferentes artes: "En el proceso creativo, por supuesto, los elementos necesarios para la realización de una obra artística varían mucho, según que ésta sea una obra plástica, literaria, escénica, etc.". También nos precisa la peculiaridad de la creación poética:

Quizá sea la poesía, la creación que con más austeridad de medios puede llevarse a cabo; para su creación nos bastará con un buen bagaje poético y literario, acompañado de unos buenos diccionarios; amén, claro está, de una buena inspiración.

F.M. señala distinciones entre las artes:

Sí, hay una diferencia; por ejemplo, un escultor que está picando piedra, de pronto, le salta un trozo de piedra por una parte con lo que no contaba y bueno, ahí puede ocurrir: que se convierta en otra cosa, hasta que tenga que tirar la piedra por no haber posibilidad de corregir. En el cine, la capacidad interpretativa de cada actor marca que puedan surgir elementos que no estaban previstos o intensidades. Sí, definitivamente sí.

Para X-X.L., no se trata de distinciones necesarias entre las artes, sino entre los creadores, como resultado de las características individuales de cada persona: "Creo que más que en las diferentes artes sería en los diferentes creadores, ya que hay diferentes formas de plantearse el proceso creativo, unos más racionales, otros más emocionales, etc.". Opinión que comparte O.V., que ve igualmente como las diferencias en estos procedimientos provienen más bien de los artistas.

J.O-Y. alude a las semejanzas entre los diversos procesos creativos de las artes:

Las diferentes artes utilizan... parecidos procesos creativos. Aparte quedan las diferencias individuales y alguna especificidad propia de artes muy técnicas y que han de tener en cuenta la seguridad de su obra como es el caso de la arquitectura, o el tener en cuenta a un equipo de colaboradores muy amplio como en el caso del cine.

Lo cual está en estrecha relación con la posibilidad de transversalidad del creador: "Los creadores que pueden estar activos y ser eficaces en distintas artes demuestran cuan próximos pueden estar los procesos creativos entre éstas".

En esta línea se encuentra V.B., que también señala la transferencia de recursos y medios entre las artes como un fenómeno cada vez más común:

Hoy en día se habla mucho del arte expandido, es decir del traspase de las herramientas y sintaxis de un arte a otro; creo que si hay cuestiones en común. Si hablamos, por ejemplo, de ritmo en base a presencias y ausencias, encontramos lo mismo en todas las artes, sean acústicas como la poesía y la música, o visuales como la pintura o la arquitectura.

unife 59 
LL.B. cree que no se pueden categorizar la manera cómo se comportan los procesos creativos: "Pueden darse procesos o estanques muy parecidos o divergentes, pero igualmente pueden darse muchas similitudes e iluminaciones de carácter muy cercano e iguales entre sí".

\section{La creación artística y otros tipos de creación}

La mayoría de los artistas manifiesta que ciertamentehay diferencias entre la creación artística y otros tipos de creación, como la científica, la industrial, etc., pero también encuentran similitudes remarcables. Una excepción la constituye P.A., quien encuentra únicamente disparidades. Para sustentar su opinión, toma como referente la actividad literaria:

Por supuesto que la hay; hoy es prácticamente imposible la creación industrial o científica en soledad, la necesidad de sofisticados medios para realizarla obliga a los 'creadores' a trabajar en equipo, cosa que en la creación literaria es prácticamente anecdótica.

I.C. señala que las diferencias entre estas formas de creación residen en su finalidad, que se resume en la búsqueda de respuestas, ausente de la creación artística:

En la finalidad sí. En la ciencia, también en el deporte, se quieren respuestas, avanzar en las metas a conseguir. Aunque en el diseño industrial sí encontramos una relación con la creación artística. La diferencia estaría en la utilidad de éste, mientras que en el arte la utilidad no existe. El arte busca: perspectivas, lecturas distintas de la realidad, nuevas, para verla y entenderla.

O.V. considera que la característica que diferencia la creatividad artística de otras formas de creación reside en sus objetivos; aunque, por otro lado, las acercan los vínculos que mantienen con el mundo: "En todos hay la relación con el mundo y la realidad, lo que los diferencia es la finalidad: la reflexión, el cambio, el progreso, la diversión".

J.O-Y. ve en su carácter, fundamentalmente no utilitario, la diferencia esencial de la creación en el arte respecto a otras formas de creación:

Creo que las diferencias vienen dadas por el distinto destino del trabajo. En la creación científica o industrial las necesidades utilitarias son más decisivas que en la creación artística. La creación artística puede dejarse definir, simplemente, como poética sin disponerse necesariamente a ser interpretada ni comprendida.

Aunque puede darse el caso de la utilización de la ciencia y la industria de formas de creación y de métodos propios a la creación artística:

La creación que se relaciona con una producción industrial o científica puede hacer uso de cualquier procedimiento poético, intuitivo, artístico, pero no podrá cerrarse en estos procesos por útiles y hermosos que resulten. Podría recordar aquí la expresión de Maxwell, descubridor del electromagnetismo, quien afirmaba que si una ecuación resultaba hermosa en su formulación, a menudo, también, acababa por ser cierta y exacta. 
La creación artística no se debe en principio a ninguna utilidad (aunque esto sería discutible), lo cual la hace más libre y por tanto más poderosa. $\mathrm{Y}$, precisamente por eso, los métodos de acercamiento al logro artístico son a menudo remedados o utilizados por no pocos científicos e ingenieros en sus búsquedas.

A.M.R. encuentra que, a pesar de las semejanzas en su desarrollo, la diferencia esencial entre las otras formas de creación y la artística la constituye el hecho de no corresponder a necesidades externas, ni a la búsqueda de soluciones; además del carácter grupal que, por lo general, poseen estos tipos de creación, amén de la frecuente delegación de la realización creativa:

Aunque las etapas del proceso pueden ser semejantes, hay en la creación industrial, científica o incluso de diseño gráfico, otros aspectos. Por ejemplo, este tipo de creación parte de una necesidad externa al individuo o grupo creador, un problema que resolver y que atañe a más a otros que al creador mismo. Además, estos tipos de creación implican proyectos grupales con dinámicas distintas, e incluyen procedimientos como los focus groups y otros, poco utilizados en la creación artística.

Para J.V., las distintas metas entre la creación artística y la científica e industrial es lo que conduce a diferenciar sus motivaciones creativas; aunque concuerden en hacer mejor al ser humano:

Son distintos los objetivos, y forzosamente han de ser diferentes los impulsos creativos, pero todos coinciden en contribuir al desarrollo de la esfera más distintiva del ser humano, la que tiene que ver con el mundo de las ideas, y su aplicación... a las necesidades individuales o colectivas.

M.P. piensa que las similitudes de todas las formas de creación se encuentran en la búsqueda de la belleza, la liberación y la utilidad:

Claro que hay diferencias, y también muchas similitudes. En términos generales toda creación sea artística, científica o industrial busca la belleza, la liberación y la utilidad; hay obras científicas de una belleza apabullante y obras artísticas de una utilidad social impresionantes...". Para ella las diferencias se hallan, no tanto, en sus objetivos o sus logros, sino en sus procesos de creación: "Sin embargo, son sus procesos creativos, diría yo sus 'modos de hacer', y no sólo sus fines o resultados específicos los que marcan la diferencia.

V.B. considera que las disparidades entre los diversos tipos de creación residen en los lenguajes. Por otro lado, apunta a las semejanzas entre la creación artística y las ciencias sociales y jurídicas: "En realidad, me ha ocurrido observar similitudes entre el trabajo artístico y el de investigación en ciencias sociales o en derecho que son mis ramas. Lo que varían son los lenguajes."

X-X.L. observa que, aunque los procesos mentales son análogos en los diversos tipos de creación, lo que los diferencia es la libertad que disfruta la creación artística: "En realidad creo que los procesos mentales son similares, pero en el caso artístico existe mayor libertad a la hora de manejar diferentes fuentes y recursos y menor número de códigos establecidos". 
Para LL.B. existen diferencias "de enfoque o detalle", pero un proceso esencial las une en una búsqueda primordial que es similar:

El modo central que es la búsqueda de algo concreto o difuso, pero que nos ocupa y obsesiona, es fundamental: tanto para un artesano en modo inventivo, un hortelano cuando se juega una cosecha, o un poeta a la pesca de una imagen o signo que anude una idea, es o puede ser y manifestarse de maneras muy semejantes.

A.G.F. no encuentra diferencias fundamentales entre estos procesos creativos, aunque pueda señalarse algunos elementos de diferenciación que no están: "ni en la mecánica, ni en el desarrollo". Pero: "Sí que hay elementos -adjetivos y sustantivos- que son identificables y diferentes entre los dos procesos creativos: el artístico y el científico".

F.M. ve diferencias que provienen de los métodos, pero también similitudes. Ella misma en el desarrollo de su actividad creadora dice sentirse muy cercana a un científico; por ejemplo:

- En la disección de los elementos sonoros con los que trabaja: "Cuando tratas de decorticar desde una palabra, una frase -para convertirla en un poema sonoro que tenga toda la musicalidad de la polisemia, el sincretismo poético y la expresividad y originalidad que deba de tener- hay que ir muy a lo hondo como va un científico cuando está mirando el núcleo de la célula".

- En la insistencia de la búsqueda: "El factor repetición del científico que vuelve y vuelve, y de ese volver y esa suma de 'aquí y ahora', de análisis y más análisis, surge, emerge, explota. Hay un momento en que se produce el descubrimiento científico".

- En la dependencia de un instrumento (su propio cuerpo, en su caso), como el científico con el microscopio: "Yo compongo desde una idea y desde el cuerpo, como un científico que necesita sus microscopios y sus cultivos. Hay diferencias. Tiene que haber diferencias en función de lo que dependes, y dependes del piano; hay gente que depende de cultivos en laboratorio, y eso sin duda hace que los procesos sean diferentes. Y también de la imaginación, del carácter del científico y del músico. Igual que hay cosas que a mí me dicta el propio cuerpo mientras estoy componiendo una obra, a un científico le puede surgir mientras él canta con su percepción, con su ojo".

- En la importancia de la coordenada temporal: "El factor tiempo es fundamental. Hay una frase maravillosa de Zeami, el creador del teatro Nôh 'conoce la semilla y conocerás la flor', no se puede conocer la flor sin conocer la semilla. Hay que sembrar, hay que repetir, hay que entrenar, hay que buscar que es más allá de probar. No es prueba/error, sino que la percepción también se agudiza por medio de esa repetición, y lo que ves al cabo de un proceso de trabajo y de repetición no lo veías al inicio, aunque la idea germen fuera la misma. No eres capaz de traducir lo mismo".

\section{La creación artística acto de expresión o de comunicación}

La totalidad de las personas que respondieron al cuestionario consideran 
que ambos procesos se encuentran indisolublemente vinculados. Ese es el sentido de la respuesta de O.V. Los demás matizan o introducen nuevos elementos.

X-X.L. señala la interrelación entre ambas funciones: "Siempre hay cierto discurso que se mezcla con la forma de expresarlo". P.A. añade otra característica: "Supongo que ambas cosas a la vez, aunque también diría que un acto irreflexivo".

A.G.F. reafirma la interdependencia de ambos actos y agrega la importancia de la atención:

Creo que una cosa va con la otra, la comunicación necesita de expresión, tanto como de atención. La atención es una pieza clave en este asunto, si es que hay algo que no lo sea. El rompecabezas está conseguido cuando las piezas encajan.

Para V.B., se trata de dos procesos indisolublemente unidos: "Cuando alguien se expresa trata de comunicar algo".

J.V. añade dos variables: la creación artística como un acto de liberación y como un acto de individualización, posibilitándole distinguirse de los demás:

Ambas, en algunos casos incluso un acto de liberación. Más aún, un acto de individualización. Al fin y al cabo, una pulsión psicológica muy presente, entre quienes huyen del comportamiento gregario, es la necesidad de diferenciarse de los demás. La originalidad creativa es una de las herramientas más acrisoladas para conseguirlo.
Según A.M.R., es posible darle preponderancia a uno o a otro, aunque atribuye la expresión al creador y la comunicación al receptor: "Uno puede dar énfasis a cualquiera de los dos aspectos. Pero pienso que en el autor pesa más la expresión y en el receptor la comunicación". M.P. afirma que además de encerrar estos dos actos, la creación permite ir más allá de lo que separa al creador del receptor, posibilitándole ir a lo más profundo de las cosas:

Las dos cosas. Y me gusta pensar que además de expresar y comunicar, permite trascender, en el sentido en que posibilita atravesar el límite que nos separa, buscar la esencia de las cosas, ser aire con todos. La voz es de las mejores herramientas sonoras para conseguirlo.

J.O-Y. considera que un buen acto expresivo debe ser también comunicativo:

En mi opinión, un buen acto expresivo es comunicativo, da cuenta de algo y de un modo que resulta accesible a algún nivel, aun para aquellos que no parecen especialmente predispuestos para una aceptación sin concesiones. Pienso en este sentido en el Guernica de Picasso que, siendo como es formalmente arriesgado y difícil, comunica un mensaje de modo tan claro que cualquiera puede darse cuenta de que se refiere al dolor y sufrimiento provocado por la guerra, haciéndolo extensible a todas ellas, más allá de su tema de partida. $\mathrm{O}$, en como durante la Edad Media se utilizó con eficacia la imagen, extraordinariamente expresiva, para comunicar al vulgo ideas religiosas de calado sin contar con su nivel cultural. 
Esta función comunicativa del acto creativo -nos precisa J.O-Y.- impide que se convierta en un mero entretenimiento:

Una obra artística que no sea capaz de establecer comunicación, de hacer llegar un mensaje, pierde la posibilidad de ser útil al receptor y, por tanto, aumentan las posibilidades de que caiga en el mero entretenimiento o que sea fácilmente banalizada. No debemos olvidar que ya Platón especulaba con la idea de que la obra de arte debiera ser útil además de bella. El mero goce estético no es suficiente sino va acompañado de otras apreciaciones, éticas, sociales, religiosas, etc.

Sobre este tema, el artista añade:

Intento en lo posible aproximar mi creación al receptor, aunque siempre contando con que lo receptores son numerosos y muy diferentes, sin olvidar que la recepción fina y especializada es escasa. Así que busco técnicas para envolver o implicar al receptor en la obra; por ejemplo: utilizar objetos o elementos que él ya conoce, que forman parte de su vida cotidiana, que no son estrictamente artísticos, ni nobles ni distantes. Este es un recurso que ayuda a hacer más corta la distancia entre la obra y el espectador. Además, utilizar la palabra escrita, los juegos de lenguaje, el humor, el erotismo, formas simples y directas sin demasiada elaboración en la composición, técnicas sencillas como girar un elemento 90 o 180 grados y con eso cambiar por completo su significado (un muro se convierte en una pasarela si lo giramos 90 grados), y de ese modo pasa de ser un objeto nuevo...
Para I.C., la creación es una necesidad vital. Un medio de expresión nos dice, que puede desarrollar la comunicación en tres vertientes posibles: comunión, rechazo o indiferencia:

Es una necesidad vital, siempre me digo ¡ya no más!, pero al mismo tiempo busco los resortes para provocar de nuevo hacer otra obra, otro proyecto. ¡Claro que sí!, es un medio de expresión en el que viertes: lo que ves, lo que has aprendido, a donde quieres llegar. Y cuando la obra es escuchada se establece la comunicación en tres direcciones: de comunión, de rechazo o de indiferencia. Las obras de arte están rodeándonos y no necesariamente tenemos que comunicar con todas. Comunicaremos cuándo, con qué y dónde lo necesitemos. El arte es una necesidad para el hombre.

En el caso de LL.B., el acto creativo es algo con la capacidad de cambiarnos y comunicar, retratándonos ante los otros, al mismo tiempo que incitándolos a hacer lo mismo o más: "Crear es apreciar, adivinar, pro-vocar iluminación capaz de cambiar en algo o en todo nuestro sentir-vivir. Desde allí, comunicar es retratarse uno mismo ante los demás y moverlos a hacer lo mismo o incluso más que uno".

Para F.M., la creación es un acto vital de expresión y comunicación. Un acto de desnudez en el que cuida que no haya nada superfluo, introduciendo en sus espectáculos la máxima concentración para poder conseguir un doble nivel de comunicación; por un lado, del creador/ artista con el público y por otro, del público consigo mismo: 
Es un acto vital. Es decir, es algo que, no solamente uno hace para los demás o con los demás (expresarse ante otros o comunicarse con otros), sino que es un proceso vital de expresión individual y de comunicación. Las dos cosas y más cosas. Es un acto de desnudez en el que te despojas. Cuando hablaba de la soledad es un poco en este sentido; lo que das ha de ser puro, no artificioso. Las retóricas sobran. En mi caso particular cuido para que no haya nada que sea decorativo, nada que distraiga y yo induzco a la máxima concentración sin decorados, y la luz está muy pensada en mí, precisamente para que refuerce esa concentración y se llegue a ese nivel de comunicación con el público, también del público consigo mismo. Es como un 'toma y daca', es como un acto de amor. Es una historia de amor, tú das, cuanto más das más recibes. Y esa energía se percibe también en el escenario y se produce un bucle de retroalimentación, una especie de dinamo. O sea que suelen ser las dos cosas, pero más cosas también.

\section{Relación del creador con el público}

...el acto creativo no es desempeñado por el artista solamente; el espectador lleva la obra al contacto con el mundo exterior por medio del desciframiento y la interpretación de sus cualidades internas y así agrega su contribución al acto creativo. Esto se hace aún más obvio cuando la posteridad da su veredicto final y algunas veces rehabilita a artistas olvidados.

(Marcel Duchamp, 1957)

- ¿Adónde pretende llevar a su receptor?

No puede darse por completado el proceso de creación sin considerar el papel que juega el receptor del mismo. El espectador, el oyente, el lector, el público tienen alguna forma de participación respecto a la obra de arte que reciben, sea esta en forma de poema, relato, pintura, escultura, grabado, música, performance, película y un largo etcétera de formas y creaciones mixtas. Con los siguientes subapartados, referidos ambos al receptor, terminamos de exponer las respuestas de nuestros creadores invitados.

Algunos artistas coinciden en el propósito de querer conducir al receptor a una observación profunda, sea esta sobre la realidad como nos señala O.V. "A una reflexión sobre la realidad"; o sea, sobre sí mismo, como es el caso de F.M.:

Si pretendo algo, es que vayan a lo más hondo de sí mismos. El arte no sirve para entretener. El arte es algo capaz de incidir en las personas que lo contemplan. Pero claro, el caldo de cultivo que hay en cada uno de nosotros es muy distinto, con lo cual la traducción actúa de modos muy diferentes según cada cual.

Esa mirada de la que nos habla F.M. permitirá que emerjan en el receptor ciertas emociones, la mayoría de las cuales serán, hasta ese momento, desconocidas para él. Es un logro del arte auténtico, sin artilugios ni falsificaciones que puedan desvirtuarlo:

Entonces, el arte verdadero, creo que permite aflorar en cada cual emociones que hasta desconocía... Ese ¡No sé qué!, es a veces el ¡No sé qué! de San Juan de la Cruz. Se puede crear una especie de química, como de enamoramiento. No de enamoramiento de alguien, sino de descubrir en uno mismo una sensación, una percepción, o que le 
emerjan frutos, flores. Plantamos, a veces semillas en el terreno de cada uno de los 'escuchantes' que están presentes, de las personas del público que son de orígenes tan diversos, y por eso el arte debe ser sincero y auténtico, estar exento de artificio, porque en el momento en que sólo quieres entretener, se convierte en artificioso y no puede llegar a lo hondo.

De esta manera el artista favorece que su receptor desarrolle su percepción. Todo lo cual supone, en sus palabras, un acto de responsabilidad de los artistas:

Tiene que ser algo esencial, fundamental, tiene que proceder de lo más hondo de la fuente de cada artista, y es allí en lo más profundo de ellos mismos, donde descubren sensaciones o emociones, o ideas que no se habían manifestado, con lo cual el artista, sin duda, contribuye a que la capacidad de percepción del que tiene enfrente aumente, además de la suya propia. Es una responsabilidad que tenemos. Me acuerdo cuando leí a Antonin Artaud, como me sentí muy identificada en mis inicios al ver como todo lo que se ve, se escucha, incide en la percepción del público, ya sean luces, vestuario, gestualidad, el movimiento, la música, lo que se dice, sobre todo cómo se dice.

J.O-Y. manifiesta que, aunque no está muy seguro de querer llevar a sus receptores a algún sitio, lo que sí desea, es aportarles una experiencia profunda. En ese sentido, coincide con F. M.: "Lo cierto es que no estoy muy seguro de quererlo llevar a algún lugar. Pero sí sé que quiero proporcionarle una experiencia que sea tan compleja, profunda o sentida como pueda darse desde mi experiencia y conocimiento". Por otro lado, le interesa acercarse al público y acortar distancias entre este y el arte contemporáneo, mostrándole cómo surgió este arte, y cuyas inquietudes están próximas a las que pueda tener:

Me doy cuenta que, de cualquier forma, me interesa buscar puntos de contacto con el receptor, reducir la distancia entre éste y el arte contemporáneo, ante el que suele haber cierto rechazo. Mostrarle como éste nació del mismo mundo cotidiano y de las mismas preocupaciones que dominan su vida.

X-X.L. nos dice que pretende conseguir una situación particular para que su receptor pueda experimentar una revelación y una emoción especiales: "...por lo general quiero que experimenten algún tipo de descubrimiento y emoción, es decir una experiencia, generando situaciones de escucha especiales, aunque sé que es difícil conseguirlo".

En esta línea se encuentra V.B., que busca transmitir emociones y sensibilizar a sus receptores en los temas que trata: "Me gusta transmitir emociones, aunque solo les dé información. Trato de que los receptores puedan hacerse más sensibles hacia los asuntos que trabajo".

I.C. distingue dos niveles en los objetivos que quiere conseguir en los receptores de sus obras. Un primer nivel con un propósito elemental: "Un primer nivel es que el oyente disfrute de la escucha de la obra". Pero su objetivo primordial busca la apropiación de la obra por parte del oyente:

Pero el fin de la obra, no solamente de las mías, entiendo que es llegar a la comunión de ésta con el oyente. Es en 
este proceso que se trasvasa la energía de la obra al oyente. Podemos decirlo con otras palabras: el oyente hace suya la obra. La puede hacer suya, bien en la medida que el autor la ha entendido o, recibirla en otras muchas direcciones.

La compositora se define como una intermediaria entre sus obras y sus receptores:

Como autora, me siento en la creación como una transmisora de las obras que genero. Rechazo el concepto de autor que hemos heredado del Romanticismo, pero comprendo que hoy en día no podemos escapar de éste. El arte está mercantilizado. Algunos autores piensan que esta puede ser una de las explicaciones de lo postmoderno. La realidad de la autoría es fruto de la sociedad en la que vivimos. No siempre fue así. El anonimato formó parte del arte durante milenios y sigue siendo así en buena parte de las artes populares. La obra no te pertenece, desde el momento que está finalizada tiene vida propia.

En este sentido, manifiesta su interés por las obras que apelan a la participación del público, además, busca despojar al arte de artificios para poder llegar al sentido y a las raíces del arte:

Me interesan las obras en la que se hace participar al público. Por otro lado, me interesa 'despojar de oropeles' la obra para llegar a la esencia de la misma, encontrar un nuevo sentido al arte. La dificultad está en que tu bagaje cultural está constantemente interfiriendo; pero podemos sentir que a veces es positivo llegando a una hibridación. Desde la electroacústica aprendí a buscar la música en las cosas cotidianas y darles sentido y significado. Solo hay que aprender a escuchar el entorno, natural o urbano. De las cosas que no podemos oír, sí que podemos imaginarlas. Un ejemplo de lo que digo sería trabajar sobre el sonido de las estrellas, como pasa en Estrelas, en Paisaxes Sonoras Imaxinarias, obra para coro y cinta realizada con Mónica Álvarez que está incluido en el CD Música e Entorno (Lugo Cultural, 2009), o el desierto, en la obra En las Estepas del Asia Central de Alexander Borodin, etc.

La idea del disfrute la desarrolla también P.A., al mismo tiempo que busca aproximar a sus receptores a su propia experiencia vital: "Simplemente a gozar de la belleza de la poesía y si fuera posible, a sentir que caminan a mi lado un trecho de mi vida".

Esa idea de compartir con el receptor la encontramos igualmente en LL.B., quien nos habla de entrar en una estrecha participación con el otro, de comunión con el receptor, como I.C, para que pueda llegar a formar parte del creador:

Arte es mil veces generosidad $\mathrm{y}$ expansión, ergo que lo que nos parece a nosotros importante e iluminador, gustamos de hacerlo público y nos congratulamos en hacer partícipes de ello a quienes nos rodean y nos son apreciables. Así pues, al hollar un terreno de novedad inusitada, lo que más nos nace es compartir, convencer, entrar en comunión con el otro devenido parte de mi mismo yo.

A.M.R. considera que el receptor hallará en la obra medios para descubrir otra forma de 
percibir el mundo, lo contrario constituiría un fracaso del creador:

El receptor deberá encontrar en la obra pequeños o grandes hitos de interés o deslumbramientos, de placer o desagrado, pero encontrar algo. Debería ayudar a desvelar de una nueva manera de sentir/pensar el mundo: $i . .$. eso era así, cómo lo había sentido/ pensado? De lo contrario nada sirvió.

A.G.F. busca desarrollar un proceso dinámico entre el creador y el receptor, con el que expresa un deseo de alianza entre ambos en su búsqueda artística:

Prefiero que me acompañen, que se unan a mi búsqueda... Esta tendencia a hacer figuras de pensamiento, como metáforas o imágenes, nos conducen siempre hacia un escenario misterioso. $\mathrm{Y}$ no lo es para nada. Tendemos a invocar al misterio cuando no entendemos o, mejor en este caso, cuando no reconocemos los resortes naturales del proceso creativo.

Para M.P., no es posible determinar un camino ni una meta para sus receptores. Ellos tienen sus propios condicionantes, códigos, entornos, contextos que orientan sus interpretaciones, al igual que ocurre con el propio creador:

A dónde ellos quieran. De hecho, yo no los llevo más que a los sitios donde sus prejuicios, sus propias experiencias, sus referentes, sus códigos, su interpretación se los permitan. Por eso, la obra de arte y en general todo el universo $\mathrm{y}$ hasta nuestros mejores amigos, familias y amantes, son siempre nuestra interpretación, nunca llegamos a conocer a nada, ni a nadie, siempre interpretamos desde nosotros. Tú me escuchas y me defines y describirás mi obra de forma muy diferente a como lo hiciera un inuit o un pigmeo africano, incluso a cómo lo hubieras hecho tú hace veinte años, o como lo haría tu alma gemela en este preciso momento.

Por último, J.V. elije, remitiéndose a Molière, una intencionalidad entre didáctica y lúdica, aunque señala que es el receptor quien, en última instancia, debe obtener sus propias conclusiones de la creación artística con la que entra en contacto:

Hay numerosos propósitos, distintos en las diferentes ocasiones, pero si tuviera que mencionar, el más acentuado de todos ellos, debo admitir, que es muy parecido al que presidió la obra de Molière: enseñar divirtiendo... Aunque reconozco que, en muchos casos, mis artefactos creativos contienen una diversión muy amarga y que mis didácticas, por la vía de la crítica social, adoptan frecuentemente una chocante ejemplaridad basada en los opuestos; por ejemplo, cuando para no resultar demasiado doctrinal, muestro las miserias del ser humano sin emitir juicios morales al respecto y dejo que sea el receptor del mensaje quien saque las conclusiones óptimas.

Papel del receptor en el proceso de creación

M.P. y LL.B. se adhieren plenamente a una concepción participativa del receptor. LL.B. incide en la intervención activa del receptor en la obra y nos habla de una relación íntima y estrecha entre el autor y su público: 
A lo largo del siglo XX ha habido muchos artistas de referencia que han dicho suo modo que es el receptor quien acaba, completa y da sentido al crear. Yo, por mis modelos en el arte más cercano e inspiradores, tanto como por mi propio andar, siempre en el filo de lo comunal como humus a fermentar y liberar arte mediante, diré y repetiré que para mí, más que para muchos otros, el arte es comunión/ symposium, symbiosis/convivium $\mathrm{y}$ hasta festejo participativo.

A.G.F. responde afirmativamente y de manera enfática a la existencia de este papel participativo. Cita un proverbio de Los Cantares de Antonio Machado que reflexiona sobre la diferencia entre lo esencial y la percepción externa de las cosas: 'El ojo que tú ves no es ojo porque lo veas, es ojo porque te ve'.

O.V. considera que el receptor al aportar su mirada sobre el proceso creativo: “...puede completarlo o destruirlo".

X-X.L. afirma que el receptor debe actuar de manera productiva y ser capaz de adelantarse al propio creador: "Creo que el papel del espectador debería ser creativo y llevar las obras más allá de las que yo o cualquier otro autor podamos pensar".

J.V. reconoce la participación activa de sus lectores y nos manifiesta sentirse muchas veces sorprendido y gratificado por las apreciaciones sobre sus obras:

Tanto y de una manera tan eficiente que, a veces, me sorprenden los análisis que algunos lectores inteligentes hacen de mis proposiciones. Ven aspectos que estaban ahí, pero en los que no fui capaz de reparar conscientemente mientras los manipulaba. Mis personajes literarios son a veces unas criaturas muy enredadoras.

A.M.R. considera que el receptor es creador porque toma de la obra lo que le atañe y la experimenta según su propia experiencia vital. Según ella, esto es lo hermoso de la creación artística, la apropiación de la obra por parte del receptor, para que sobrepase a su creador y cobre vida propia:

Sí, el lector, como diría Eco, es también un creador, pues recoge de la obra lo que le interesa, llena cabos sueltos, se deslumbra por una parte o aspecto de la obra o la deshecha, la hace vivir según su propia vida.

Eso es lo bello de la creación artística: que alguien se apropie de ella, la recree, la odie, la ame, la aprecie, te haga reflexionar, pero que no te sea indiferente. La obra cobra así vida propia y transciende a quien la creó.

I.C. cree que más que completar el proceso de creación, el receptor lo recrea. Para la compositora, cada tipo de expresión artística entronca con diversos segmentos de la sociedad:

No lo completa, desde mi punto de vista lo versiona, lo recrea, lo integra en su esquema cultural, sensorial, etc. No se entendería de otra forma, que sigamos escuchando a Mozart. Hay muchos niveles en el arte y, creo sinceramente, que todos son importantes. Cada tipo de expresión artística conecta con personas que pertenecen, quizás, a segmentos diferentes de población, como sucede con las telenovelas. ¿Por qué las vamos a rechazar de plano? 
Aunque en la actualidad como músico me causa mucho enfado ciertas músicas urbanas, perfectas tecnológicamente, pero vacías. Tenemos más tecnología. Sí, pero ¿Esto nos hace profundizar en las cosas? o ¿Todo queda en la superficialidad más elemental?

F.M. nos da una respuesta distinta sobre la actuación del receptor en el proceso de creación. Para ella, su obra siempre termina en escena, aunque las circunstancias particulares del público harán que pueda tener diversas lecturas, y que su interpretación y sentido sean diferentes. Hay tantas lecturas como receptores, pero la obra pertenece al creador; según su opinión, las posibles lecturas no varían ni influyen en la obra; ni, en su caso, en ella:

La obra culmina en escena, porque en escena pasan todas las cosas que vengo mencionando, lo que sucede es que según la procedencia intelectual geográfica, social, edad, etc., de cada persona del público la lectura puede ser distinta, y lo que para unos significa una cosa, para otros significa otra diferente; pero esto es subjetivo y depende de cada cual. Con lo cual, mi obra es mi obra. Si no fuera lo que es, no produciría lo que produce en cada cual; pero, sí que es como un árbol que se ramifica, como un árbol que tiene un tronco, un eje muy consistente, muy sólido y que se ramifica en tantas personas como hay en el público y en tantas lecturas; pero claro, eso a mí no me puede influir: ¡si da alegría a unos, lo que a otros les hace llorar!

Sin embargo, matiza, la multiplicidad de lecturas que puede generar la obra, la dotan de un valor añadido:
Así que, hay tantas lecturas como personas en el público, pero la obra que se emite es la misma; claro que, las lecturas del público dan una gran riqueza, quizás, habría que pensar en hacer una post-obra después de analizar qué es lo que a cada cual le produjo.

Algunos de nuestros entrevistados, aunque están de acuerdo en principio con el papel activo del receptor, son algo recelosos respecto a su cumplimiento en la práctica. J.O-Y. considera que debería ser así; pero añade que desgraciadamente no se cumple, la razón es la pasividad del receptor, que a veces, carece de los recursos que le permitirían cumplir ese papel, buscando solo el entretenimiento, transformando la obra de arte en un objeto más de consumo rápido:

Más que creer que lo completa, quisiera creer que lo hace, porque eso daría más valor e interés a nuestro trabajo, que se vuelve cada vez más penoso, solitario e inútil. En mi opinión, y tengo motivos para creer que es un pensamiento extendido, el receptor se ha vuelto mayoritariamente pasivo y demasiado ávido de novedades y entretenimiento como para tener un papel claro en el 'redondeo' de la obra.

Esta actitud del receptor, según J.O-Y., no es sino la consecuencia de la ausencia de formación y de criterios válidos para poder valorar las obras de arte, que caracterizan a una parte de la sociedad en nuestros días:

Para que el receptor pueda completar el proceso de creación parece lógico que disponga de un bagaje cultural $o$, en su defecto, de una actitud de 
respeto, cuando no de veneración, hacia la obra artística; y si, como ocurre a mi entender, ninguna de estas virtudes se está dando en esta época, tan dada a entretenerse y tan enemiga del pensamiento y la profundidad, la hermosa y emocionante experiencia de sentir la obra completada por el espectador, veedororeceptoresmás rara aún que en los tiempos fundacionales de la modernidad. Entonces incluso el rechazo, la incomprensión, el ataque intelectual o físico a la obra tenían un valor real para completarla, para darle entidad y eficacia.

De allí, la asimilación del objeto artístico a la sociedad de consumo, lo que, de alguna manera, le hace perder su verdadera esencia:

En su lugar ahora encontramos una falta de reacción, más allá de la meramente vinculada al pasatiempo, que da cuenta de lo que realmente parece que pasa: ya no se ve la obra artística como un medio privilegiado de conocimiento, de conocimiento del mundo y de uno mismo y de transformación de ambos. El creador sabe que hoy la obra es un objeto de consumo, generalmente rápido y que, por tanto, la comunicación ni mucho menos la 'colaboración' mistificante, con el receptor le está vedada por el signo de los tiempos.

En esa misma línea, se manifiesta V.B., quien piensa que lo que predomina es la necesidad creativa del autor, pero dentro de un contexto social y económico en el que no se dan las condiciones que permitan o propicien esa labor activa del receptor:
Claro que sí, aunque si esperamos a tener un receptor en países donde no hay mercados de arte o literatura tal vez no crearíamos nada. Por eso, es preciso también persistir en la creación por propia necesidad o placer, aunque esa es una solución como el sexo en solitario; sería mejor hacer todo lo posible, para que comunidades enteras puedan darse el gusto o satisfagan la necesidad de crear y participar como receptores de la creación.

P.A. es aún más escéptica: "Me gustaría decir que sí, pero esas son siempre meras especulaciones, no creo que mi poesía sea 'circular', espero que ésta vuele sin condiciones una vez que escapa de mí'”.

\section{CONCLUSIONES}

- Este trabajo es un paso inicial que debe completarse acrecentando el corpus reducido que hemos empleado, haciendo llegar los cuestionarios a más artistas y ampliando los campos artísticos de los entrevistados. Este incremento permitiría una valoración más completa de los resultados.

- A pesar de la variedad de pareceres, las respuestas tienen muchos puntos de convergencia y, en algunos casos, de similitudes que nos llevan a pensar en ciertas tendencias o concepciones artísticas que "flotan en el aire" de los tiempos que corren la postmodernidad.

- Otro aspecto interesante es, que en líneas generales y a pesar de su diversidad, las respuestas dan lugar a un relato coherente con unidad discursiva, aunque constatamos algunas discordancias, pero que incluso en este caso, vemos como aspectos complementarios. 
- Los temas presentes en los cuestionarios de los artistas son principalmente: el arte como vuelta a los orígenes, el carácter "nuevo" y "diferencial" del objeto artístico, la creación como acto natural y volitivo, la creación como un proceso que permite aflorar "algo" que aguarda en lo profundo del artista, la creación como iluminación, como hecho vital, como poética, y la fuerza del inconsciente en ella. Otros temas son: el aprendizaje y la preparación como requisitos, el arte como mirada a la realidad, el arte como contracultura, el arte como búsqueda de la belleza.

- Los momentos que configuran el desarrollo del proceso creativo, según los artistas consultados, lo forman un conjunto de etapas. Tomando las opiniones vertidas de los participantes, podemos elaborar un prototipo que sintetice este proceso. La mayoría distingue una fase previa como antesala del proceso creativo. En esta se encuentra la idea inicial, el germen (que puede proceder de otros proyectos o ideas), el concepto que darán lugar a la labor creativa. Esta etapa estará seguida por un período de reflexión, de investigación, de búsqueda de material, de delimitación de las herramientas adecuadas, la determinación del tipo de obra a realizar. El paso siguiente está constituido por la realización de la obra, dar forma a la idea, manipularla, estructurarla, seguidas del ajuste o perfeccionamiento de lo que se está elaborando. Es importante considerar dos factores en estos procesos: el ritmo de alternancia de las etapas que cambia según cada obra y cada creador, y el papel que juega el tiempo como factor de maduración del trabajo creativo.
Finalmente, tendremos el resultado final que, en ciertos casos, no se adecuará al concepto inicial del creador al haber sufrido transformaciones durante el proceso de creación.

- En lo que se refiere a las condiciones requeridas por los artistas para el desarrollo de su tarea creativa, encontramos algunas peculiaridades distintivas tanto como semejanzas. Lo cual es una lógica consecuencia de las características personales de los individuos. Algunas se refieren a escenarios materiales o circunstancias externas: seguridad económica, tranquilidad, silencio, espacio físico para trabajar, adecuación del espacio al proyecto en el que trabaja, tiempo y otras; más bien, hacen referencia a condiciones internas del creador. Saber lo que se quiere decir, motivación, escucha, imaginación, disfrutar de un estado especial de percepción y soledad, estar alerta, ser capaz de vaciarse de contenidos superfluos para propiciar la creación.

- Con relación al modo de desarrollar su trabajo creativo, aparte de dos entrevistados que manifiestan repetir el mismo esquema, la práctica de la totalidad manifiesta adaptar su forma de trabajar al tipo de obra que va a realizar, aun en el caso de reconocer aspectos definidos que suelen mantener como norma general.

- En cuanto a las diferencias en el proceso de creación de las diferentes artes, aparte de dos excepciones de un creador que no las encuentra, y otro que ve rotundamente diferencias sin especificarlas, la mayoría de los creadores enfoca las similitudes y 
disparidades con variables diversas. Para ciertos entrevistados, las diferencias dependen, tanto de las artes como de los artistas; otros ven estas distinciones en los propios creadores y otros en las distintas artes con su diversidad de técnicas y de materiales. Otros entrevistados tienen una postura integradora, en la cual la creación artística es un fenómeno que goza de una unidad que no es fácil de separar a pesar de sus distinciones circunstanciales. Hay quien ve un impulso y un eje común en gran parte de las formas de creación en el arte por encima de las diferencias. Otros señalan que lo que las une es la transferencia de medios, la transversalidad de las artes hoy en día, y quien considera que en los procesos de creación artística, todas las posibilidades de convergencia, divergencia y similitudes se encuentran abiertas.

- La manera de enfocar las diferencias y/o semejanzas con otros tipos de creación, como la científica o la industrial, son dispares. Hay quien solo apunta a diferencias más bien relativas al entorno del creador, que se resumen en la necesidad de soledad para la creación artística; quienes, a pesar de las diferencias, encuentran similitudes entre todas las formas de creación; y una mayoría que encuentra que las disparidades, en estos tipos de creación, residen en sus diferentes objetivos utilitarios (para las no artísticas) y en el empleo de diferentes lenguajes o la libertad de la que goza esta creación (para las artísticas).

- En lo que concierne a la relación de la creación con la comunicación y la expresión, algunos autores las ven necesariamente vinculadas, aunque también encontramos quien las separa, atribuyendo la expresión al creador y la comunicación al receptor. También constatamos la identificación de la creación como expresión y comunicación con un acto de desnudez por parte del creador. Asimismo, un grupo vive estas dos funciones unidas al acto creativo, añadiéndole otras funciones como: la de la liberación y la de la individualización. Asimismo, la atención, la irreflexividad, la capacidad de cambiarnos, la capacidad de llevar al creador a la comunión con el receptor, la posibilidad del rechazo o a la indiferencia del receptor constituyen otros factores que hemos constatado. Finalmente, hay quien piensa que, sin negar la participación de ambas, en la creación se trata de trascender esta dicotomía y buscar la esencia de las cosas.

- Tocante a dónde quiere el artista conducir a su público, encontramos dos grupos de planteamientos. Uno, que representa a la mayoría de los entrevistados, para quienes la obra es mediadora para los distintos propósitos de los creadores: conducir a sus espectadores a una reflexión sobre la realidad, acercarse al receptor con una intención entre didáctica y lúdica; encontrar en la obra los medios para descubrir una manera nueva de percibir y comprender el mundo; hacer que el receptor dirija su mirada a lo más hondo de sí mismo; transmitirle o llevarlo al descubrimiento de nuevas emociones o hacerle partícipe de sus propias emociones, proporcionarles experiencias profundas; acercarse al público; crear una alianza con el receptor; acortar distancias entre el 
público y el arte contemporáneo; y gozar de la belleza. Otro grupo de creadores sale del circuito creadorobra-receptor. En estas concepciones, el autor busca compartir su obra con el público. Dentro de esta concepción, podemos distinguir dos planteamientos: una postura consiste en declinar cualquier propósito para con el receptor y dejarlo en libertad de hacer el recorrido que desee o sea capaz; otra, transformar la obra en el vehículo para entrar en comunión con el receptor. Aquí, encontramos dos vertientes: en una, el receptor pasa a integrarse con el autor; en otra, el receptor se apropia de la obra que, al estar terminada, adquiere vida propia y deja de pertenecer a su creador.

- Referente al papel activo del receptor en la creación, hay un caso en el que no se le reconoce ese papel, planteándose más bien que de lo que se trata es que la obra genera múltiples lecturas en el público, que varían según sus circunstancias particulares; lo que hará variar, a su vez, en un proceso subjetivo el significado de la obra para esas personas, sin modificar la obra. Al lado de esta opinión, un grupo mayoritario se adhiere a aceptar la intervención del receptor en el proceso de creación. Esta concepción se manifiesta sea como una proyección del creador (que desearía que el receptor cumpla un papel creativo y que lleve las obras más allá de su propio autor), sea en el reconocimiento de la participación del receptor. En este último caso, encontramos varios niveles: a) un primer nivel en el que esta participación se muestra a través de las apreciaciones de los receptores; b) un segundo nivel, en el que el receptor experimenta las obras según su propia experiencia vital; c) un tercer nivel, lo encontramos en el carácter lúdico y en la búsqueda de comunión con el público que los une en la obra; d) un último nivel, que subraya aún más la intervención del receptor, planteando que lo que hace el receptor es más bien dar lugar a una recreación de la obra, que luego integrará en su esquema vital y cultural.

- Finalmente, algunos artistas creen que ese papel corresponde a circunstancias ideales que desgraciadamente no se cumplen en la actualidad y ponen en entredicho el papel activo del receptor, debido a causas sociales y culturales, ya que piensan que, en la sociedad en la que vivimos, el arte tiende a ser un objeto de consumo más, y el receptor se ha transformado en un sujeto pasivo. Reconocen que no existen mercados que faciliten una actitud activa del receptor, pero que a pesar de ello se reafirma en la necesidad de perseverar en la creación y en la participación como receptores activos de esta. Una postura más extrema es la que afirma que se trata de especulaciones en las que no cree y que lo que desea es que sus obras circulen sin ataduras una vez puestas en el mundo. 


\begin{abstract}
ANEXOS
Pilar Álvarez ${ }^{4}$ Poeta

1) ¿Qué es para usted la creación?

Según la RAE, la creación es la acción de dar existencia a una cosa a partir de la nada; ahora bien, no es posible atenerse a este principio si queremos hablar de "creación literaria"; sin memoria, sin atender a los pasos seguidos por los que nos precedieron, es imposible que esa creación se pueda realizar.
\end{abstract}

\title{
2) ¿Cree que hay momentos diferenciales en este proceso?
}

Por supuesto, cualquier estilo literario del que hablemos precisa de un trabajo previo, investigación, recopilación de datos, experiencias previas, etc., y a partir de ahí comienza el verdadero acto de creación.

\section{3) ¿Qué condiciones requiere poner en práctica un proceso creativo?}

Decía Virginia Woolf que toda mujer para ser creadora necesitaba una habitación propia y 500 libras de renta anual, porque solo la libertad permite la creación; hoy sigue siendo válida esa afirmación.

\section{4) ¿Tiene modo de trabajo definido o este varía según la obra?}

Podría decirse que hay un modo de trabajo que se repite en todas mis obras: escribo de noche y corrijo o desecho en la mañana.

\section{5) ¿Cree que hay diferencias entre la creación artística y otros tipos de creación, como la creación científica, la industrial, etc.?}

Por supuesto que las hay; hoy es prácticamente imposible la creación industrial o científica en soledad; la necesidad de sofisticados medios para realizarla obliga a los "creadores" a trabajar en equipo, cosa que en la creación literaria es prácticamente anecdótica.

\section{6) ¿Cree que hay diferencias en el proceso creativo de las diferentes artes?}

En el proceso creativo, por supuesto, los elementos necesarios para la realización de una obra artística varían mucho, según que esta sea una obra plástica, literaria, escénica, etc. En este caso, quizá sea la poesía la creación que con más austeridad de medios puede llevarse a cabo; para su creación, nos bastará un buen bagaje poético y literario, acompañado de unos buenos diccionarios; amén, claro está, de una buena inspiración.

4. Nace en Toledo, aunque pasa un largo período de su vida en Asturias, actualmente reside en Los Alcázares (Murcia). Publicaciones: Cosas mías (Poesía), Auto Edición, 2013; La orilla (Poesía), Ediciones Ibermón, 2016; Entredós (Poesía), Ezencia, 2018.

Socia fundadora de LaEcocultural, asociación sin ánimo de lucro dedicada a la difusión ecológica y cultural. En la actualidad, es la vocal de cultura de esta asociación, que programa diversos actos, tales como: presentación de libros, concursos educativos con los alumnos de los institutos del Campo de Cartagena, paseos históricos para dar a conocer la historia de los Alcázares, y nuestro acto más importante del año: La Playa de los Libros (que supone un encuentro entre los autores de todo el sureste español, sin que ello cierre el paso a cualquier autor de otras latitudes). 


\section{7) ¿Adónde pretende llevar a su/s receptor/es?}

Simplemente a gozar de la belleza de la poesía y, si fuera posible, a sentir que caminen a mi lado un trecho de mi vida.

\section{8) ¿Su creación artística es un acto de expresión, de comunicación o de las dos cosas?}

Supongo que ambas cosas a la vez, aunque también diría que es un acto irreflexivo.

\section{9) ¿Cree que el receptor completa su proceso de creación?}

Me gustaría decir que sí, pero esas son siempre meras especulaciones, no creo que mi poesía sea "circular", espero que esta vuele sin condiciones una vez que escapa de mí.

Llorenç Barber ${ }^{5}$. Músico, compositor, teórico, musicólogo y artista sonoro.

\section{1) ¿Qué es para usted la creación?}

Crear es percibir una cierta iluminación mediante la cual algo nace y crece en nosotros, capaz de sugerir, producir, conceptualizar, argumentar y mostrar un algo más o menos inquietante e incierto, que puede cambiar/mejorar/discernir en algo nuestro entender/ disfrutar o el de otros que tengan acceso a ello.

\section{2) ¿Cree que hay momentos diferenciables en este proceso?}

Veces hay que sí, pues las percepciones pueden darse en pequeñas diócesis, tragos, saltos y acercamientos que mejoran y complementan y completan ese iluminador atisbo inicial; y veces hay, por contra, en que todo se da de un solo soplo, como Paulo cayendo súbitamente del caballo.

\section{3) ¿Qué condiciones requiere para poner en práctica un proceso creativo?}

Unas veces, las más, estar en un cierto "tono" de percepción, soledad, calentamiento de mientes e intuiciones en torno a algo que nos es problema a discernir: es base desde la

5. Nació en Ayelo de Malferit, (Valencia) en 1948. Introductor del minimalismo musical en España, cercano al movimiento Fluxus, formó parte del Grupo ZAJ. Su música tiene propuestas innovadoras como la música plurifocal, en sus conciertos de campanas, llamados conciertos de ciudad y realizados por todo el mundo: Río de Janeiro, México, Barcelona, Santiago de Chile, Madrid, Lugo, Vallarta o Yokohama, etc. Naumaquias en los años noventa, entre buques, cañones, tambores, fuegos artificiales, sirenas en Cartagena. Conciertos de los Sentidos, Conciertos Itinerantes. Sus conciertos se extienden a la naturaleza en sus conciertos de Sol a Sol desde 1991 en la finca el Arreciado, Toledo. Escribe varios volúmenes dedicados a músicos contemporáneos, entre ellos: John Cage, Mauricio Kagel, publicados por el Círculo de Bellas Artes. En 1978 funda el Taller de Música Mundana, dedicado a la música improvisada, del que salieron propuestas como la Ópera para papel. Director del "Aula de música" de la Universidad Complutense de Madrid en 1979-1984. Forma parte del Flatus Vocis Trio, junto a Fátima Miranda y Bartolomé Ferrando a partir de 1987. Participa como colaborador en el programa "El Mirador" de RTVE, desde 1987 hasta 1990. Director de "Paralelo Madrid-otras músicas" (1992). Funda el festival "Nits d'Aielo" 1998, dedicado al arte experimental, y lleva la dirección de los conciertos "Paralelo Madrid" en el Círculo de Bellas Artes (1992).

Ha publicado numerosos escritos entre ellos libros de relevancia entre los que están: El placer de la escucha. Madrid: Ardora. 2003. Músiques d'intempèrie. Tarragona: Arola. 2009. La mosca tras la oreja. De la música experimental al arte sonoro en España con Montserrat Palacios, Madrid: Fundación Autor - SGAE. 2010. 
cual incubar algo es lo más natural. Otras veces, ese "tono" no se da, pero se dio, se buscó, se intuyó, sin llegar a adivinar o percibir esa luz postulada o buscada con ahínco, y de repente estando aparentemente en distracciones, algo se ilumina y se nos da como un regalo, una fruta madurada, entera y ya caliente para ser degustada y aparentemente sin esfuerzo alguno.

\section{4) ¿Tiene un modo de trabajo definido o este varía según la obra?}

Crear es, las más de las veces, algo bien "caprichosón", que tiene su propio querer, sus propios modos, planos, maneras de desvelarse, etc.; lo que un día vale no lo valdrá el siguiente. Con todo, el estar en estado de vigilia/búsqueda/desembrolle, etc., lo es todo. "No te buscaría" decía Agustín de Hipona, "si no te hubiera encontrado".

\section{5) ¿Cree que hay diferencias entre la creación artística y otros tipos de creación, como la creación científica, la industrial, etc.?}

Puede haber diferencia de enfoque o detalle, pero el modo central que es la búsqueda de algo - concreto o difuso, pero que nos ocupa y obsesiona- es fundamental: tanto para un artesano en modo inventivo, un hortelano cuando se juega una cosecha, o un poeta a la pesca de una imagen o signo que anude una idea; toda creación es -o puede ser y manifestarse- de maneras muy semejantes.

\section{6) ¿Cree que hay diferencias en el proceso creativo de las diferentes artes?}

Pueden darse procesos o estanques muy parecidos o divergentes, pero igualmente pueden darse muchas similitudes e iluminaciones de carácter muy cercano e iguales entre sí.

\section{7) ¿Adónde pretende llevar a su/s receptor/es?}

Arte es mil veces generosidad y expansión, ergo, lo que nos parece a nosotros importante e iluminador, gustamos de hacerlo público y nos congratulamos en hacer partícipes de ello a quienes nos rodean y nos son apreciables. Así pues, al hollar un terreno de novedad inusitada, lo que más nos nace es compartir, convencer, entrar en comunión con el otro devenido parte de mi mismo yo.

\section{8) ¿Su creación artística es un acto de expresión, de comunicación, o las dos cosas?}

Crear es apreciar, adivinar, provocar iluminación capaz de cambiar en algo o en todo nuestro sentir-vivir. Desde allí, comunicar es retratarse uno mismo ante los demás y moverlos a hacer lo mismo o incluso más que uno.

\section{9) ¿Cree que el receptor completa su proceso de creación?}

A lo largo del siglo XX, ha habido muchos artistas de referencia que han dicho suo modo que es el receptor quien acaba, completa y da sentido al crear. Yo, por mis modelos en el arte más cercano e inspiradores, tanto como por mi propio andar, siempre en el filo de lo comunal como humus a fermentar y liberar arte, diré y repetiré que, para mí, más que para muchos otros, el arte es comunión/symposium, symbiosis/convivium y hasta festejo participativo. 


\section{Violeta Barrientos Silva ${ }^{6}$. Poeta}

\section{1) ¿Qué es para usted la creación?}

Me gustaría decir que la creación artística es mi trabajo, pero no llega a dar para vivir. Así que amplío el término de "creación" para otros rubros, a fin de que sea mi trabajo, ya que es lo que quiero hacer. Es un impulso y a veces llega a ser una necesidad. La necesidad de expresión interna, también el placer de que algo nuevo exista, porque cambia al mundo de alguna manera. Es necesidad y placer al mismo tiempo.

\section{2) ¿Cree que hay momentos diferenciables en este proceso?}

Sí, dependiendo el tamaño y complejidad de la obra, reconozco que hay un impulso primero, que a veces llega más fácil que otras en que es necesaria una autoinducción (es como cuando se ha dejado de hacer gimnasia y debe estar en forma). Luego, si es una obra compleja, hay un momento de investigación y de reunir materiales para llevar a cabo la creación.

\section{3) ¿Qué condiciones requiere para poner en práctica un proceso creativo?}

Espacio físico, temporal y referentes (ver qué está hecho y qué se podría hacer). A veces se crea en condiciones más confortables y otras, en condiciones de guerra. Ambas son estimulantes.

\section{4) ¿Tiene un modo de trabajo definido o este varía según la obra?}

Por lo general, es el mismo en cuanto a etapas. Luego, claro que cambia, según el contenido de la obra.

\section{5) ¿Cree que hay diferencias entre la creación artística y otros tipos de creación, como la creación científica, la industrial, etc.?}

En realidad, me ha ocurrido observar similitudes entre el trabajo artístico y el de investigación en ciencias sociales o en derecho, que son mis ramas. Lo que varían son los lenguajes.

\section{6) ¿Cree que hay diferencias en el proceso creativo de las diferentes artes?}

En la actualidad, se habla mucho del arte expandido, es decir, del traspase de las herramientas y sintaxis de un arte a otro; creo que sí, hay cuestiones en común. Si hablamos, por ejemplo, de ritmo en base a presencias y ausencias, encontramos lo mismo en todas las artes, sean acústicas como la poesía y la música, o visuales como la pintura o la arquitectura.

6. Violeta Barrientos Silva, nació en Lima en octubre de 1963. Aunque manifestó una vocación artística temprana, por
presión familiar debió estudiar derecho en un país con pocas oportunidades para una carrera literaria. A la vez, terminó
la carrera de literatura en la Universidad Católica, universidad con marcada influencia de la literatura hispánica, pero
única facultad a salvo de la violencia política que duró una década en el Perú. Su primer libro Elíxir, fue publicado en
1991. Publicó en 1992, El innombrable cuerpo del deseo, primer poemario con temática lésbica publicado en Perú.
Viajó ese mismo año a París a seguir un doctorado en Literatura y Estudios Latinoamericanos, donde también trabajó
en el área de los derechos humanos y derechos de la mujer. Se doctoró en la Universidad de París VIII en 2001 con
una tesis sobre la representación del cuerpo en la poesía peruana del siglo XX. Volvió a Perú en 1999 y desde 2003
incursionó en el campo de los estudios relativos a la sexualidad y al género, trabajando en proyectos internacionales
de defensa de los derechos sexuales y de la mujer. Se dedica también a la docencia en estos campos.
Otras publicaciones destacables son: El jardín de las delicias (1999), Tragic/Comic (2003) y Cosas sin nombre (2008). 


\section{7) ¿Adónde pretende llevar a su/s receptor/es?}

Me gusta transmitir emociones, aunque solo les dé información. Trato de que los receptores puedan hacerse más sensibles hacia los asuntos que trabajo.

\section{8) ¿Su creación artística es un acto de expresión, de comunicación o las dos cosas?}

Ambas cosas. Cuando alguien se expresa trata de comunicar algo.

\section{9) ¿Cree que el receptor completa su proceso de creación?}

Claro que sí, aunque si esperamos tener un receptor en países donde no hay mercados de arte o literatura, tal vez no crearíamos nada. Por eso, es preciso también persistir en la creación por propia necesidad o placer, aunque esa es una solución como el sexo en solitario; sería mejor hacer todo lo posible, para que comunidades enteras puedan darse el gusto o satisfagan la necesidad de crear y participar como receptores de la creación.

Inmaculada Cárdenas ${ }^{7}$. Músico, pedagoga, artista sonora y multimedia.

\section{1) ¿Qué es para usted la creación?}

Crear es el único verbo que empleamos al hablar para referirnos a Dios y para el trabajo que realizan los artistas. Crear es sacar algo de la nada, de donde no hay. Es curioso como la religión, el invento más completo del hombre, para explicar lo que no tiene explicación, estuviera unida en los orígenes del hombre a la magia y al arte. El mago era a la vez el que tenía los secretos de lo no visible, y para demostrar su poder utilizaba la magia.

7. Nace en La Línea (Cádiz) en 1952. Catedrática del área de música de la Universidad de Santiago de Compostela hasta su jubilación en 2013. Dedicada a la investigación de musicología hasta su llegada a Lugo, se dedicará desde entonces a la investigación en pedagogía musical. Funda el Grupo de Creación Musical de la USC (GCUMUS) en 1997, luego llamado Grupo de Creación Sonora (GCSUS). Codirectora de los Sons Creativos. Pertenece a la Asociación de Músicos Electroacústicos de España AMEE. La relación de sus obras se encuentra en el Diccionario de la Música Española e Hispanoamericana editado por la SGAE.

Las obras de Inmaculada Cárdenas están inscritas en las maneras electroacústicas de composición, aunque buscando siempre una forma propia de expresión, ha hecho guiños a otros estilos musicales. Gusta de estar en las fronteras de las artes, le fascinan las relaciones entre música y pintura, música y escultura, música y arquitectura, música y palabra. Trabaja con grupos de personas con las que ha realizado trabajos pedagógicos que han culminado en intervenciones sonoras en espacios arquitectónicos. En sus obras hay un trasfondo dramático que ella define como música cinemática y que Denis Dufour llama "cine para los oídos".

Sus creaciones están publicadas en CDs como: Concierto para Esculturas Sonoras (1992), Música y Arquitectura (2001) y la Ópera Serea e o Contador de Contos (2002), por la Fundación ACA de Mallorca y en DVDs: O Grupo de Creación Sonora en Concerto (2004), Música e Entorno (2009) y Música, Espazos e Cidade (2012), publicados por Lugo Cultural. Una parte de sus obras se encuentra en el net label alg-a y en la web de los Sons Creativos: www. sonscreaativos.com, más información sobre los Sons Creativos en: www.sonscreativos.weebly.com

Entre sus escritos pioneros en la Pedagogía de Creación Sonora en España está su monografía Evolución de la Pedagogía Musical. La Pedagogía de Creación Musical (2003). Ha impartido cursos y conferencias en España y el extranjero: Ciudad de México, Lecco (Italia), Lima (Perú), Palencia, Santander, Santiago, Campo Criptana (Ciudad Real), Olivares (Sevilla), Cuenca, etc.

Sus obras han sido programadas en foros nacionales e internacionales, como Synthése en Bourges (Francia), Hemisferic en Nueva York, Universidad de Bolonia, Fonos en Barcelona y el CDMC en Madrid. Recientemente en Miami, Berlín y Bilbao. 
Cuando las culturas se hicieron más complejas, la magia se desdobló en religión y arte. De esta forma, la historia del hombre ha transitado siglos de prehistoria e historia. El hombre era la encarnación de Dios. Dice la Biblia "hecho a su imagen y semejanza". Esta visión homocéntrica del universo en la que el hombre es la criatura privilegiada y todo lo demás está a su servicio, va a cambiar en el siglo XX. La visión romántica del mundo va a cambiar por completo. Los descubrimientos de la ciencia -el otro pilar en el que se asienta la humanidad- van a ayudar a ese cambio de mentalidad. En el siglo XX, muchos artistas, pensadores y científicos ven al hombre integrado en el mundo. Estas premisas las comento para decir que la creación para mí, como para algunos artistas actuales, es un proceso que vuelve la mirada al origen. François Baylle, músico electroacústico continuador de la obra de Pierre Schaeffer en el GRM de París, decía en uno de sus escritos "la obra me encuentra" $y$, efectivamente, esa era mi percepción de lo que pasaba en mis procesos de creación antes de leer a Baylle. En mi caso, hay una parte que denomino mágica y que es sorprendente.

Cuando comienzas con la idea de hacer una obra, tienes el tema genérico que puede ir cambiando y a partir de aquí, como de un hilo de una madeja, progresivamente todo se va abriendo. Decía Llorenç Barber: "la música está ahí, sólo hay que escucharla y cogerla".

\section{2) ¿Cree que hay momentos diferenciables en este proceso?}

Sí, el primero sería saber qué obra quieres hacer. En mi caso, ha podido ir desde obras electroacústicas, hasta obras experimentales, improvisadas, pasando por obras audiovisuales, intervenciones sonoras, etc. El segundo momento consiste en ver el material con el que quieres trabajar, que puede ir desde objetos cotidianos -he realizado obras con muchos objetos y muebles de mi casa, cerámicas, etc.- hasta todo tipo de instrumentos clásicos, populares y étnicos, inventados y construidos para la obra, como hicimos en Concierto para Esculturas Sonoras y en la Ópera Serea e o Contador de Contos. El material con el que se trabaja es importante porque sus sonoridades van a orientar y definir la obra. El tercer momento es cuando ya tienes el material sonoro (temas o materias sonoras en el caso de la música electroacústica, generadas con la manipulación, en laboratorio, de grabaciones reales). A partir de aquí, puedes comenzar a elaborar un primer boceto de obra, que puedes cambiar a lo largo del proceso. Estamos hablando de la estructura de la obra. Por último, está el ajuste en detalles para darle unidad y redondez a la misma.

\section{3) ¿Qué condiciones requiere para poner en práctica un proceso creativo?}

Ninguna en especial. Se me pueden ocurrir desde las ideas a los temas en los sitios más diversos, paseando en una cafetería. Pero, cuando estoy trabajando en la obra, ahí sí requiero del silencio y la tranquilidad para concentrarme.

\section{4) ¿Tiene un modo de trabajo definido o este varía según la obra?}

Varía según la obra, ya que hacer una obra electroacústica es muy diferente, en su proceso, que realizar una obra improvisada para instrumentos, o una intervención sonora. Por otra parte, cuando trabajas en solitario las reglas -que en el arte siempre las pone el autor- eres tú quien las controla. Si trabajas tú solo, vas eligiendo estos recursos, y vas desgranando las entradas y los temas. 
Muchas de mis obras son obras cerradas desde su finalización y se conservan en un soporte, de manera que son un objeto material, como un cuadro. Por ello, entiendo que se pueden presentar, tanto en concierto como en exposiciones, como la exposición de los Sons Creativos 25 Anos de Pedagogía e Arte Sonora en Lugo, en el MIHL (Museo Interactivo da Historia de Lugo). Todo cambia cuando trabajas en un proceso de creación en grupo. Hay que explicar qué quieres y ponerse de acuerdo. En mi caso, la improvisación forma parte de mi manera de componer. Por tanto, si los músicos no tienen un nivel de improvisación adquirido, entra en acción mi faceta pedagoga.

\section{5) ¿Cree que hay diferencias entre la creación artística y otros tipos de creación, como la creación científica, la industrial, etc.?}

En la finalidad sí. En la ciencia, también en el deporte, se quieren respuestas, avanzar en las metas a conseguir. Aunque en el diseño industrial sí que encontramos una relación con la creación artística. La diferencia estaría en la utilidad de este, mientras que en el arte la utilidad no existe. El arte busca perspectivas, lecturas nuevas y distintas de la realidad, para verla y entenderla.

\section{6) ¿Cree que hay diferencias en el proceso creativo de las diferentes artes?}

A nivel de la creación, hay un impulso común entre las artes. Pero, cada arte en particular encamina sus técnicas por diferentes recorridos, que están ligados a los materiales con que trabajan: el sonido, el color, la materia sólida, la palabra, etc. Lo que sí creo, es que hay un eje común entre las artes, que podríamos decir que es el gesto. Este es evidente en la música, la pintura, la danza o en la arquitectura tradicional. En literatura estaría en la poesía, en el gesto vocal, el ritmo de las palabras, etc.

\section{7) ¿Adónde pretende llevar a su/s receptor/es?}

Un primer nivel es que el oyente disfrute de la escucha de la obra. Pero el fin de la obra, no solamente de las mías, entiendo que es llegar a la comunión de esta con el oyente. Es en este proceso que se trasvasa la energía de la obra al oyente. Podemos decirlo con otras palabras: el oyente hace suya la obra. La puede hacer suya, bien en la medida que el autor la ha entendido, o recibirla en otras muchas direcciones. Como autora, me siento en la creación como una transmisora de las obras que genero. Rechazo el concepto de autor que hemos heredado del romanticismo, pero comprendo que hoy no podemos escapar de este. El arte está mercantilizado. Algunos autores piensan que esta puede ser una de las explicaciones de lo postmoderno. La realidad de la autoría es fruto de la sociedad en la que vivimos. No siempre fue así. El anonimato formó parte del arte milenios y sigue siendo así en buena parte de las artes populares. La obra no te pertenece, desde el momento que está finalizada tiene vida propia. Me interesan las obras en las que se hace participar al público. Por otro lado, me interesa 'despojar de oropeles' la obra para llegar a la esencia de la misma, encontrando un nuevo sentido al arte. La dificultad está en que tu bagaje cultural está constantemente interfiriendo, pero podemos sentir que, a veces, es positivo llegar a una hibridación. Desde la electroacústica aprendí a buscar la música en las cosas cotidianas y darles sentido y significado. Solo hay que aprender a escuchar el entorno, natural o urbano. De las cosas que no podemos oír, sí que podemos imaginarlas. Un ejemplo de lo que digo 
sería trabajar sobre el sonido de las estrellas, como pasa en Estrelas en Paisaxes Sonoras imaxinarias, obra para coro y cinta realizada con Mónica Álvarez, que está incluida en el CD Música e Entorno (Lugo Cultural, 2009), o sobre el sonido del desierto, en la obra En las Estepas del Asia Central de Alexander Borodin, etc.

\section{8) ¿Su creación artística es un acto de expresión, de comunicación, o las dos cosas?}

Es una necesidad vital, siempre me digo ¡ya no más!, pero al mismo tiempo busco los resortes para provocar nuevamente y hacer una obra, un nuevo proyecto. Claro que es un medio de expresión en el que viertes lo que ves, lo que has aprendido, a donde quieres llegar. Y cuando la obra es escuchada, se establece la comunicación en tres direcciones: de comunión, de rechazo o de indiferencia. Las obras de arte están rodeándonos y no necesariamente tenemos que comunicar con todas. Comunicaremos cuándo, con qué y dónde lo necesitemos. El arte es una necesidad para el hombre.

\section{9) ¿Cree que el receptor completa su proceso de creación?}

No lo completa, desde mi punto de vista lo versiona, lo recrea, lo integra en su esquema cultural, sensorial, etc. No se entendería de otra forma que sigamos escuchando a Mozart. Hay muchos niveles en el arte y creo, sinceramente, que todos son importantes. Cada tipo de expresión artística conecta con personas que pertenecen, quizás, a segmentos diferentes de población, como sucede con las telenovelas. ¿Por qué las vamos a rechazar de plano? Aunque en la actualidad como músico me causa mucho enfado ciertas músicas urbanas, perfectas tecnológicamente, pero vacías. Tenemos más tecnología, sí ¿Pero esto nos hace profundizar en las cosas? o ¿Todo queda en la superficialidad más elemental?

\section{Augusto García Flores ${ }^{8}$.}

\section{1) ¿Qué es para usted la creación?}

Un acto natural y volitivo en el ser humano en tanto que se dé una característica, o una serie de condiciones y facultades imprescindibles para que den lugar al acto creativo.

8. Director de teatro. Actor de reparto en compañías profesionales por toda España. Guión y locución en la Emisora del Campus de Middlebury College, Vt., USA, de 1972 a 75. Guión, documentación y presentación del programa de Flamenco "Oído al Cante” (Radio Peninsular y Radio Nacional), España, Campo de Gibraltar (de 1978 a 81).

Ha impartido cursos en: el Middlebury College, de 1972 a 75; la Escuela de Teatro S. Roque, de 1979 a 82; en la Escuela de Teatro La Línea, de 1982 a 85. Talleres de Teatro en la Escuela Universitaria de Magisterio V de Europa, UCA 1985-86. Cursos de Improvisación, de Creación, en Ofertas Esc. Municipales, S Roque y La Línea.

Entre sus publicaciones están: "Eslabón" en La Línea; "Bahía” en Algeciras; "Verde Blanco" en Málaga; "Guadalmesí" en Tarifa; "Tres Orillas" en Algeciras; "Almoraima" y "Dos Orillas" en Algeciras. Publica en el Libro antológico $1^{\circ}$ Col. Verde/Blanco, Alas para la Poesía Andaluza, Málaga 1978 y en el Libro antológico El Campo de Gibraltar en la Poesía Española, Jerez, 1985. Colaboraciones en prensa en los diarios Área, Europa Sur, en revistas como: La Línea Cultural, Carteya en Madrid. Margaritas como moscas será Premio de Poesía Guadalmesí 2001. "El fragante esplendor" obtiene una Mención de Honor en XV Premio Victoria Kent, 2009. "Poetas de esta noche" será Mención de Honor XII en Encuentros por la Paz, 2014. Las obras "La llamita", "Playa de levante para siempre" e "Ícaro" serán seleccionadas para los Premio de poesía "Luz", "Los mejores poemas”, Ed. Imagenta, Tarifa, 2015, 2016 y 2017.

Título de RESAD, Madrid 1974, equivalente a Licenciado por el Ministerio de Educación. Seminario de Teatro en Medina del Campo (Valladolid, 1982). Crea y organiza el I Concurso de Teatro Nacional de aficionados "Ciudad de La Línea”. Tiene una voz propia en el Diccionario Enciclopédico Provincia de Cádiz, Producciones Cinterco, 1985. 


\section{2) ¿Cree que hay momentos diferenciables en este proceso?}

Puede ser, aunque no creo que siempre sea igual ni siquiera en la misma persona.

\section{3) ¿Qué condiciones requiere para poner en práctica un proceso creativo?}

Supongo que te refieres a lo personal... Bueno, es complicado. Pero creo que es imprescindible saber qué se quiere expresar. Alguien dijo que si no hay nada que decir, es mejor quedarse callado. Luego viene un recurrir al conocimiento o a la experiencia personal, trasladarlo o componerlo a modo para que se identifique lo más posible con la idea, o el ideal, que ha movido todo; quizás sea mejor decir: removido.

\section{4) ¿Tiene un modo de trabajo definido o este varía según la obra?}

Sí que varía, nunca hay nada igual, aunque muy semejante, eso sí. Pero nunca se sabe cómo ha de venir ni resultar. Creo que las teorías que hay sobre la "inspiración" son metáforas que pueden ayudarnos a definir todo este proceso, incluso las más lamentables.

\section{5) ¿Cree que hay diferencias entre la creación artística y otros tipos de creación, como} la creación científica, la industrial, etc.?

No, ni en la mecánica ni en el desarrollo. Sí que hay elementos adjetivos y sustantivos que son identificables y diferentes.

\section{6) ¿Cree que hay diferencias en el proceso creativo de las diferentes artes?}

No, en el proceso no. Creo que lo dicho antes vale para este caso también.

\section{7) ¿Adónde pretende llevar a su/s receptor/es?}

Prefiero que me acompañen, que se unan a mi búsqueda. Esta tendencia a hacer figuras de pensamiento, como metáforas o imágenes, nos conducen siempre hacia un escenario misterioso. Y no lo es para nada. Tendemos a invocar al misterio cuando no entendemos o, mejor en este caso, cuando no reconocemos los resortes naturales del proceso creativo.

\section{8) ¿Su creación artística es un acto de expresión, de comunicación, o las dos cosas?}

Creo que una cosa va con la otra, la comunicación necesita de expresión, tanto como de atención. La atención es una pieza clave en este asunto, si hay algo que no lo sea. El rompecabezas está conseguido cuando las piezas encajan... Por eso todos los aspectos, que conozcamos, son de igual importancia. Bienvenidos sean también los no conocidos porque, aun si todavía no los vemos, son muy importantes.

\section{9) ¿Cree que el receptor completa su proceso de creación?}

Naturalmente. Hay muchos dichos, incluso populares, que confirman esta gran verdad. Cito a Antonio Machado: "El ojo que tú ves no es ojo porque lo veas, es ojo porque te ve". 
Xoán-Xil López’9 . Artista sonoro e investigador

\section{1) ¿Qué es para usted la creación?}

En primera instancia un proceso de aprendizaje que finalmente se transforma en un trabajo artístico que busca explicar/contar algo o generar algún tipo de emoción. Es una forma de relacionarme con el mundo, de conocerlo.

\section{2) ¿Cree que hay momentos diferenciables en este proceso?}

Desde luego. En mi caso, una obra o proyecto suele surgir de un interés por algo concreto: un sonido, un acontecimiento, una sensación. Pero al principio suelen ser ideas muy difusas que luego intento formalizar profundizando algo más en su esencia, para finalmente, darles forma a través de una construcción artística que puede utilizar diferentes técnicas o formas de representación: instalación sonora, composición, texto, performance, etc.

\section{3) ¿Qué condiciones requiere para poner en práctica un proceso creativo?}

Pues necesito cierta inactividad, no estar demasiado ocupado con la vida misma y dejarme llevar un poco. Creo que hay que vaciarse para ofrecer espacio al azar, al tedio, etc., a todas esas cosas que intentamos desterrar de nuestra vida por considerarlas improductivas.

\section{4) ¿Tiene un modo de trabajo definido o este varía según la obra?}

Pues, aunque estoy seguro de que tengo algunos procesos de los que no soy consciente del todo, ya que no soy muy analítico o introspectivo a este nivel, por lo general cada obra parte de algo sutil, y para poder desarrollarlo suelo adaptar el proceso a la obra que quiero formalizar.

\section{5) ¿Cree que hay diferencias entre la creación artística y otros tipos de creación, como la creación científica, la industrial, etc.?}

En realidad, creo que los procesos mentales son similares, pero en el caso artístico existe mayor libertad a la hora de manejar diferentes fuentes y recursos y menor número de códigos establecidos.

\section{6) ¿Cree que hay diferencias en el proceso creativo de las diferentes artes?}

Pues no necesariamente. Creo que más que en las diferentes artes sería en los diferentes creadores, ya que hay diferentes formas de plantearse el proceso creativo, unos más racionales, otros más emocionales, etc. Pero no es un tema sobre el que tenga mucha información.

\footnotetext{
9. Su trabajo gira en torno a la práctica fonográfica (grabación de campo) y la experimentación sonora, adquiriendo la forma de instalaciones, situaciones inmersivas de escucha, composiciones, performances y textos.

Estudió musicología y se doctoró en Bellas Artes con la Tesis Señal/Ruido. Algunos usos del paisaje sonoro en el contexto del arte, centrada en la utilización de los sonidos ambientales en la creación contemporánea.

Forma parte de los proyectos Mediateletipos (arte sonoro), Ulobit (improvisación) y Voltage Opposite (danza), y colabora con diferentes formaciones como el ensemble de música contemporánea Vertixe Sonora, la compañía Gigacircus o la propuesta de música electrónica Haarvöl; es uno de los co-fundadores de Escoitar.org, colectivo interdisciplinar dedicado al estudio del paisaje sonoro y la auralidad (dimensión cultural de la escucha), activo desde 2006 a 2016.
} 


\section{7) ¿Adónde pretende llevar a su/s receptor/es?}

Pues por lo general quiero que experimenten algún tipo de descubrimiento y emoción, es decir una experiencia, generando situaciones de escucha especiales, aunque sé que es difícil conseguirlo.

\section{8) ¿Su creación artística es un acto de expresión, de comunicación, o las dos cosas?}

Ambas. Siempre hay cierto discurso que se mezcla con la forma de expresarlo.

\section{9) ¿Cree que el receptor completa su proceso de creación?}

Por supuesto. Creo que el papel del espectador debería ser creativo y llevar las obras más allá de las que yo o cualquier otro autor podamos pensar.

Fátima Miranda ${ }^{10}$. Cantante, compositora, performer e investigadora

\section{1) ¿Qué es para usted la creación?}

El proceso de creación es muy largo y amplio y se extiende a lo largo de toda una vida, aunque las obras que vayan construyéndose o ejecutándose sean diferentes, así que, al final, cada obra viene a ser el registro de una parte de un proceso vital que culmina; en mi caso, en el escenario, en una especie de ritual o acto de maravillosa soledad elegida, para la que uno se ha venido preparando durante un largo período con el fin de llegar a la máxima perfección. De tal manera que, una obra, aunque ya esté compuesta, a la hora de ponerla en el escenario se convierta en un aquí y ahora único, con una fuerza y una energía especial que es la que corresponde a ese momento, el cual no puede constar en partitura, ni puede constar en la composición de la obra. De manera que la creación, que es un término un poco delicado (porque hace parecer como que los artistas fuéramos seres todopoderosos o dioses o santos) es un término así como raro. Vamos a entender el término creación de una manera más coloquial que literal.

10. Nace en Salamanca. Cantante, compositora, performer e investigadora. Realiza estudios de Historia del Arte y se especializa en Arte Contemporáneo, publicando dos libros sobre arquitectura y urbanismo.

Entre 1983 y 1993 estudia bel canto con Esperanza Abad, María Dolores Ripollés, Jesús Aladrén y Evelyne Koch, con el fin de poder asociar unas y otras técnicas vocales. En 1987-1988 estudió en París técnicas vocales tradicionales con la japonesa Yumi Nara, gracias a una beca concedida por la Fundación Juan March. En 1988 aprende canto difónico mongol en el Museo del Hombre de París con Tran Quang Haï (consistente en la producción simultánea de dos emisiones vocales: la nota fundamental como bordón y la melodía producida por su serie de armónicos).

Sus composiciones tocan varios géneros desde las canciones folclóricas de Mongolia a la música Dhrupad india, llegando a una técnica propia donde funde estos aprendizajes. Desarrolla un lenguaje musical propio que ha mostrado en escenarios de todo el mundo. En sus performances se borran las fronteras entre canto, poesía, teatro, composición, improvisación e interpretación.

Con Llorenç Barber forma el grupo Taller de Música Mundana y posteriormente del grupo Flatus Vocis Trio, dedicado a la poesía fonética.

Reconocida con la Medalla de Oro al Mérito en las Bellas Artes en 2018, anteriormente recibe el Premio Nacional Cultura y Comunicación en 1985. En 1996 recibe la beca DAAD, siendo invitada como artista en residencia en Berlín. En 2009 recibe el Premio Internacional Demetrio Stratos para la música experimental.

Su discografía abarca desde: Las Vocesde la Voz (1992), Concieto en Directo (1994), Concierto en Canto (1996), Arte Sonado (2000), Cantos Robados (2005), ;MADrid MADrás MADrid! (2007), perVERSIONES (2011), aCuerdas (2004), Living Room Room (2016). 
El arte es poética, poesía, sí, también, pero poética. Poiētikế en griego es construcción, hay un componente de construcción. Vivimos tiempos de mucho mecanicismo y donde la gente depende más del azar, de una maquinita de video, un MP3 o cualquier ordenador que todo el mundo lleva metido en el bolso, o en un teléfono móvil, que dé una formación o dé un entrenamiento de la percepción del propio artista, sea física, en el caso de los bailarines o de los cantantes, o sea intelectual. Uno puede tener ya un alcance poético en su vida, pero todo esto se nutre y va evolucionando y así va creciendo el componente poético de la obra. Creo que lo tiene también la obra de algunos científicos, no hay más que leer a Ramón y Cajal y a Einstein.

Es muy importante, pero también, es cierto que hay miles de personas que se consideran, o que se creen artistas, en las que su obra tiene que ver con algo mucho más mecanicista que poético, y hay obras cada vez más carentes de alcance poético y de nivel conceptual. Es decir, es como comemos, crecemos, nos nutrimos, pues, también depende de la nutrición de nuestra vitalidad. Si somos curiosos y salimos, y si entramos y miramos la obra de otros, si leemos y guardamos silencios y hacemos alguna práctica interior que nos ponga en situación de entrenamiento neuronal, esto podía también formar parte de los procesos, y al final, todo se relaciona con todo. Insisto, hay muchos artistas que no son tales en absoluto y que se autodenominan así. Bueno, cada uno se conforma con lo que quiere, se consuela con lo que puede, pero a veces no hay ni un atisbo de carácter poético, ni conceptual y la obra tiene que estar respaldada por la idea o por ese alcance poético, si no, no es arte.

\section{2) ¿Cree que hay momentos diferenciables en este proceso?}

Sí creo que hay momentos diferenciables en este proceso. A veces una idea que va a ser el germen de una obra tiene origen en un momento lejano y depende del método de trabajo de cada cual; pero, como yo las ideas las suelo archivar por medio de un registro sonoro, o por medio de notas, sucede que no abordo la creación de la obra en ese momento, sino que tengo fases en que me dedico a un trabajo vocal estrictamente de perfeccionamiento, de investigación de técnicas vocales; hay otros momentos en que me concentro en el trabajo compositivo. Ese momento del trabajo compositivo es cuando reúno las ideas y me doy cuenta de que, a lo largo de una línea de tiempo largo, serán constantes. Entonces, voy asociando estas constantes para dar estructura y forma a la obra. Ese sería el segundo momento después del germen inicial. Hay un tercer momento cuando dentro del proceso de creación, en mi caso, al haber un trabajo extremo vocal, pues una cosa es la melodía o la idea y otra cosa es aquello que es posible y cuando lo pasas por el cuerpo; el mismo te trae respuestas, te trae nuevas ideas y el germen inicial se convierte en, no en otra cosa, sino que efectivamente es como un inicio, lo que se tenía luego se va construyendo a medida que se va haciendo. Después de una búsqueda y un ajuste de lo que son los recursos vocales, de lo que se quiere transmitir con esa composición, se llega a la composición propiamente. Aquí, se pasa a otra fase, que es la de cantar, cuando el gesto te lleva a imaginar una luz, un cierto color, un cierto vestuario, o un cierto recorrido. La parte gestual es muy importante, y la estática, gestual en cualquier caso, culmina en el escenario.

Es muy importante, pero también es una fase, es decir es como comemos, crecemos, nos nutrimos, pues también depende de la nutrición de nuestra vitalidad. Si somos curiosos y salimos, y si entramos y miramos la obra de otros, si leemos y guardamos silencios y 
hacemos alguna práctica interior que nos ponga en situación de entrenamiento neuronal, esto podía también formar parte de los procesos. Al final, todo se relaciona con todo. Y es, cuando la obra se libera de la técnica, cuando aparece. Pero, hay gente que no trabaja la técnica, luego no puede olvidar lo que no ha trabajado. Para la obra es fundamental (liberase de la técnica), que el resultado emerja del olvido de todo, de todo lo que uno tenía planteado; aunque la obra haya llevado un proceso desde una idea que se tuvo, una técnica que se manejó, unos instrumentos, unos elementos, unas herramientas. Lo cierto es que, al final de pura repetición y entrenamiento y revisión, emerge algo más que es como una crema, algo muy sutil. Y, cuando tienes que presentarla en escena, más aún, el arte tiene que estar desprovisto completamente de técnica; bueno, no debe notarse, tiene que estar dentro de la esencia de la semilla, pero no debe notarse. La técnica es un aspecto fundamental, no es una etapa, porque es algo que se nota continuamente. Es fundamental en todo proceso de creación; hay que estarla cultivando hasta que uno se muera, para que la obra justamente sea inmortal. Esto es algo trabajoso, tiene un componente de sacrificio, pero no tanto como se entiende en la tradición cristiana de sufrir, sino de acto sagrado, sacrificio de un acto sagrado, de crecimiento personal. Y la repetición siempre te da entrenamiento: es lo que convierte a la obra en algo único, es decir en la obra de un autor determinado por su sello.

\section{3) ¿Qué condiciones requiere para poner en práctica un proceso creativo?}

Es algo contradictorio. Por una parte, has de estar bien nutrido, has de nutrirte, has de vivir en un compromiso de entrenamiento constante y de atención. El artista ha de nutrirse, porque no somos seres ungidos por el conocimiento o por la musa; las musas no existen, las musas son generalmente cantamañanas. Lo que existe es el trabajo, bien es verdad que hay personas que nacen con una vocación especial para el trabajo creativo. Hay gente que nace (?), pero lo descubre posteriormente como pueda ser mi caso; hay gente y artistas que trabajan de una forma más mecánica y que se crean un horario, por ejemplo para componer los miércoles de 4 a 10. Claro yo con esto no puedo. No solamente no podría componer, sino que tampoco me lo creo. Del proceso creativo forma parte la vida entera y de lo que se come se cría. Por su parte cuando se trabaja con la voz hay una parte interior muy importante, porque la voz es afuera y es adentro. Es cuerpo, es fisicidad pura; más de 200 músculos intervienen, pero a veces es aire, no se puede ver, no se puede tocar y no tiene un instrumento con herramientas externas, como para saber dónde hay que dar, tocar; no se tiene en cuenta con la tensión de una cuerda un clavijero, una caja de resonancia externa al cuerpo. Hay casos de compositores que componen para otros, en mi caso lo hago para mí misma; el entrenamiento es de importancia capital y la repetición porque justamente la repetición no existe, lo que viene de diferente procede de la repetición de esa repetición que no existe porque como decía Heráclito no te bañarás nunca en el mismo río. Entonces hay que estar alerta también para cuando te viene la idea y lo que decía que era contradictorio es porque tienes que estar nutrido pero a la vez se tiene que producir un vacío; para que algo se llene tiene que estar disponible y a veces estamos llenos de demasiados estímulos, de demasiada información, de demasiado querer decir algo y a veces es del abandono de donde emergen grandes ideas y grandes obras. Siempre y cuando a esa intuición que acontece en momentos de abandono se le una un trabajo sistemático. La intuición sin un trabajo sistemático es completamente estéril y no sirve a nada. 


\section{4) ¿Tiene un modo de trabajar definido o este varía según la obra?}

Hay aspectos de la creación que son definidos como lo que hablo en relación con el instrumento y, a veces, la ejecución depende de cuestiones varias, desde dificultades de tipo vocal, hasta dominio de un pequeño instrumento que me pueda acompañar y que he de dominar. De pronto, el instrumento me cuenta cosas diferentes y entonces la obra evoluciona en función de lo que el instrumento te dice; me estoy refiriendo en particular a mi obra "Entre Salamanca y Samarcanda", donde el bordón y los armónicos del instrumento iban tirando de mí: fonemas, palabras que yo no tenía previstas y, que se fueron construyendo desde el registro en el que yo tenía que cantar, dependiendo de la cantidad de agua que había en el instrumento, y un registro te lleva a un tipo de fonema y otro te lleva a otro. En Cantos robados estoy en un traje de tres metros de altura y el hecho de que yo me acompañe de juguetitos aparentemente insignificantes (pero esos juguetes tienen su tono y su frecuencia) y por estar tan elevada y subida sobre una falda de tres metros de altura, te lleva a un gesto y ese gesto te lleva también a ciertas emisiones vocales, etc. Es decir, que hay elementos que son fijos en el proceso y otros que son variables, casi más en función de elementos externos. A veces, la idea viene de algo que escuchas en la calle, desde un claxon, hasta el ruido de una puerta, o de un timbre o algo que encuentras en un anticuario, y esto ya te da una serie armónica. Y otras veces, te viene de una emoción o de un acorde que te proporciona una máquina industrial, o de la nada, del silencio: dentro de ese 'vacío' y esas fases de 'vaciado' que son tan importantes para el artista.

\section{5) ¿Cree que hay diferencias entre la creación artística y otros tipos de creación, como la creación científica, la industrial, etc.?}

Sí, claro que hay diferencias; es decir, la metodología es distinta, pero hay elementos comunes. Yo a veces me siento muy próxima, muy próxima a un científico, o a un bibliotecario (porque he sido bibliotecaria), a un cirujano. Cuando tratas de decorticar una frase desde una palabra, para convertirla en un poema sonoro que tenga toda la musicalidad de la polisemia, el sincretismo poético y la expresividad y originalidad que deba de tener, hay que ir muy a lo hondo como va un científico cuando está mirando el núcleo de la célula. El factor repetición del científico que vuelve y vuelve, y de ese volver y esa suma de "aquí y ahora", de análisis y más análisis, surge, emerge, explota. Hay un momento en que se produce el descubrimiento científico. Entonces hay elementos de orden poético. Hay gente que compone desde el silencio y frente al papel, y yo compongo desde una idea y desde el cuerpo, como un científico que necesita sus microscopios y sus cultivos. Hay diferencias, tiene que haber diferencias en función de lo que dependes, dependes del piano; hay gente que depende de cultivos en laboratorio y eso sin duda, hace que los procesos sean diferentes. Y también de la imaginación y del carácter del científico y del músico. Igual que hay cosas que a mí me dicta el propio cuerpo mientras estoy componiendo una obra, a un científico le puede surgir mientas él canta con su percepción, con su ojo. Pero el factor tiempo es fundamental. Hay una frase maravillosa de Zeami, el creador del teatro Nôh "conoce la semilla y conocerás la flor": no se puede conocer la flor sin conocer la semilla. Hay que sembrar, hay que repetir, hay que entrenar, hay que buscar que es más allá de probar. No es prueba/error, sino que la percepción también se agudiza por medio de esa repetición, y lo que ves al cabo de un proceso de trabajo y de repetición, no lo veías al inicio, aunque la idea germen fuera la misma. No eres capaz de traducir lo mismo. 


\section{6) ¿Cree que hay diferencias en el proceso creativo de las diferentes artes?}

Sí, hay una diferencia; por ejemplo, un escultor que está picando piedra, de pronto, le salta un trozo de piedra por una parte con lo que no contaba y bueno, ahí puede ocurrir: que se convierta en otra cosa, hasta que tenga que tirar la piedra por no haber posibilidad de corregir. En el cine, la capacidad interpretativa de cada actor marca que puedan surgir elementos que no estaban previstos o intensidades. Sí, definitivamente sí.

\section{7) ¿Adónde pretende llevar a su/s receptores?}

Si pretendo algo, es que vayan a lo más hondo de sí mismos. El arte no sirve para entretener. El arte es algo capaz de incidir en las personas que lo contemplan. Pero, claro, el caldo de cultivo que hay en cada uno de nosotros es muy distinto, con lo cual la traducción actúa de modos muy diferentes según cada cual. Entonces, el arte verdadero creo que permite aflorar en cada cual emociones que hasta desconocía. Ese ¡no sé qué!, es a veces el ¡No sé qué! de San Juan de la Cruz. Se puede crear una especie de química, como de enamoramiento. No de enamoramiento de alguien, sino de descubrir en uno mismo una sensación, una percepción, o que le emerjan frutos, flores. Plantamos, a veces, semillas en el terreno de cada uno de los "escuchantes" que están presentes, de las personas del público que son de orígenes tan diversos, y por eso el arte debe ser sincero y auténtico y estar exento de artificio, porque en el momento en que solo quieres entretener se convierte en artificioso y no puede llegar a lo hondo.

Tiene que ser algo esencial, fundamental, tiene que proceder de lo más hondo de la fuente de cada artista, y es allí en lo más profundo de ellos mismos, donde descubren sensaciones o emociones, o ideas que no se habían manifestado, con las cuales el artista, sin duda, contribuye a que la capacidad de percepción del que tiene enfrente aumente, además de la suya propia. Es una responsabilidad que tenemos. Me acuerdo cuando leí a Antonin Artaud, como me sentí muy identificada en mis inicios al ver como todo lo que se ve, se escucha, incide en la percepción del público (ya sean luces, vestuario, gestualidad, el movimiento, la música, lo que se dice, sobre todo, cómo se dice).

\section{8) ¿Su creación artística es un acto de expresión, de comunicación, o las dos cosas?}

Es un acto vital. Es decir, es algo que, no solamente uno hace para los demás o con los demás -expresarse ante otros o comunicarse con otros- sino que es un proceso vital de expresión individual y de comunicación. Las dos cosas y más cosas. Es un acto de desnudez en el que te despojas. Cuando hablaba de la soledad, es un poco en este sentido, lo que das ha de ser puro, no artificioso. Las retóricas sobran. En mi caso, particular cuido para que no haya nada que sea decorativo, nada que distraiga y yo induzco a la máxima concentración sin decorados y, la luz está muy pensada en mí, precisamente para que refuerce esa concentración y se llegue a ese nivel de comunicación con el público, también del público consigo mismo. Es como un "toma y daca", es como un acto de amor. Es una historia de amor, tú das, cuanto más das más recibes. Y esa energía se percibe también en el escenario y se produce un bucle de retroalimentación, una especie de dinamo. O sea, que suelen ser las dos cosas pero más cosas también.

\section{9) ¿Cree que el receptor completa su proceso de creación?}


La obra culmina en escena, porque en escena pasan todas las cosas que vengo mencionando, lo que sucede es que según la procedencia -intelectual geográfica, social, edad, etc., de cada persona del público- la lectura puede ser distinta, y lo que para unos significa una cosa, para otros significa otra diferente; pero esto es subjetivo y depende de cada cual. Con lo cual, mi obra es mi obra. Si no fuera lo que es, no produciría lo que produce en cada cual; pero, sí que es como un árbol que se ramifica, como un árbol que tiene un tronco, un eje muy consistente, muy sólido y que se ramifica en tantas personas como hay en el público y en tantas lecturas; pero claro, eso a mí no me puede influir: ¡si da alegría a unos, lo que a otros les hace llorar!

Me acuerdo una vez en el teatro romano de Cartago, en el que actuaba con 49 Tuaregs en Túnez y uno de los Tuaregs se partía de risa, ja saber que ancestro le despertaría aquella obra!, Cuando en la zona de Tsassile y Tamanrasset han encontrado cuevas rupestres en pleno desierto donde hay pececillos, ¡A saber! No sabemos qué le evocaría. Así que, hay tantas lecturas como personas en el público, pero la obra que se emite es la misma; claro que las lecturas del público dan una gran riqueza; quizás, habría que pensar en hacer una post-obra después de analizar qué es lo que a cada cual le produjo.

\section{Jesús Otero-Yglesias ${ }^{11}$. Pintor y Artista.}

\section{1) ¿Qué es para usted la creación?}

Tanto el proceso como el acto de la creación son de una gran importancia en mi vida. No solamente por su repercusión en el trabajo que ejerzo, sino como componente de una forma de ser y estar en el mundo. La creatividad es, además de una herramienta para desarrollos estéticos, una forma eficaz, a menudo hermosa y sorprendente de solucionar problemas y conflictos, de hacer más vivo lo cotidiano y más ricas las relaciones sociales.

La creación sitúa a quien la ejerce en el centro de lo más fino y necesario de la sociedad. En mi caso, la creación ha cambiado de significado con el paso del tiempo. En un principio, tenía un claro matiz hedonista. El placer derivado de poner en marcha la creación resulta muy atractivo y deriva en momentos de gran concentración y, recientemente, con un fuerte componente de auto-realización. Con el paso de los años, y aún manteniendo este hedonismo, ha ido emergiendo una mayor conciencia de la responsabilidad que la creación implica. Creo que la sociedad espera diferentes cosas del creador, algunas opuestas entre

11. Nace en Lugo, se forma en distintos talleres y cursos con destacados artistas nacionales e internacionales como Joan Fontcuberta, Jannis Kounellis, Bruce McLean o Gabriel Orozco. Después de formar parte de distintos colectivos artísticos, comienza una carrera en solitario a partir de 1986. Inicialmente dedicado a la pintura, irá derivando hacia una mayor preocupación por los objetos, la instalación, y las acciones, en los que muestra su interés por la percepción ampliada de la realidad, la ironía conceptual o los juegos de lenguaje, así como por el uso del humor o la ambigüedad. Participa de las colectivas más importantes de Galicia, como "Galicia, Terra Única" y en la mayor parte de las ediciones de la Mostra Unión Fenosa. Exposiciones colectivas en España, Bélgica, Italia, Francia y Japón, e individuales en Madrid, Santiago de Compostela, Palma de Mallorca, Bruselas, Amberes, etc.

Entre otros premios, ha recibido el Gran Premio de Honor de la Real Academia de Bellas Artes de A Coruña; el Premio Pilar Juncosa y Sothebys de la Fundación Pilar y Joan Miró de Mallorca; así como distinciones, como el tercer premio en el certamen de los Premios Europa de la ciudad de Ostende (Bélgica). 
sí. En cualquier caso, es de la mayor importancia que su trabajo contribuya a hacer más comprensible y aceptable el mundo, que puede quedar fácilmente opacado bajo las capas de información e inconsciencia que nos rodean, alienando la consciencia y el pensamiento. Hacer esto requiere conocimiento, sutileza, intuición, capacidad para la ambigüedad y otras que son propias de la creatividad en su conjunto.

Por utilizar una analogía, la creación ha pasado con el tiempo de ser un juego a ser una jugada, o un conjunto de jugadas, sobre un tablero del mundo, sus hechos y declaraciones (a modo de ajedrez), en el que se debe conseguir resultados que trasciendan el mero entretenimiento y las estéticas de masas. La creación, para mí, tiene cada vez más el carácter de oposición, o, si se quiere, de resistencia ante la cultura hegemónica, una forma de contracultura necesaria.

\section{2) ¿Cree que hay momentos diferenciables en este proceso?}

Desde mi punto de vista, y en lo que respecta a mi trabajo, sí los hay. La creación parece ser un proceso que ponga en marcha diferentes niveles del funcionamiento cerebral. Niveles que tendrían que ver con la primera tópica freudiana: subconsciente, preconsciente y consciente. En el proceso de buscar una idea, de darle origen o forma, los primeros momentos, días, incluso meses, parecen estar dominados por una cierta confusión y círculos viciosos en los que no parece fácil evitar lo evidente, las facilidades ya adquiridas y conocidas. No cediendo a estos pobres avances, queriendo que acudan nueva ideas y asociaciones, puede ocurrir que vayan emergiendo nuevas y, a menudo, insospechadas soluciones o enfoques. Parece, en tal caso, que se haya dado un trabajo inconsciente que, algunas veces, es percibido bajo la sensación de que algo esté a punto de ocurrir, afín con la expresión "tener algo en la punta de la lengua", pues, aunque no lo percibimos con claridad nos damos cuenta de la posibilidad cierta de recordarlo, como acaba ocurriendo tras un cierto tiempo. A mí me parece un proceso de conocimiento parecido. Creo que este trabajo subconsciente se favorece con una aceptación pasiva, en principio, de cualquier buena idea por irrealizable, ilógica, o extraña que parezca, y un proceso paralelo, aunque parezca contradictorio, de descarte, de decirse a uno mismo: ¡esto no es! ¡esto no es!, ¡ esto tampoco! hasta que, finalmente, aparece la idea que se adecúa a lo que buscábamos o nos resulta satisfactoria. Así que hay procesos oscuros de los que no nos damos cuenta, aunque los podemos incentivar con la insistencia en la investigación de la idea y la búsqueda de nuevas fuentes de información y conocimiento. Estos procesos son seguidos por otros preconscientes en los que tenemos la percepción de que estamos a punto de encontrar algo, lo cual sostiene la confianza en un resultado final favorable. Finalmente, momentos de consciencia, o incluso de iluminación o revelación repentina, que pueden aparecer sin el paso previo de la percepción preconsciente, en los que se pasa de la obscuridad a la luz, por así decirlo, de un modo bastante repentino.

El proceso de creación como de emergencia desde niveles difusos a otros de mayor claridad puede estar acompañado también de sensaciones físicas, al punto de no pocas veces saber que hemos llegado a una buena idea o solución cuando el momento va acompañado de una percepción física de bienestar o de paz, que con el tiempo se vuelve reconocible y seña de progreso en el proceso creativo. El cuerpo parece, por tanto, tan importante en el proceso de creación como la mente. 


\section{3) ¿Qué condiciones requiere para poner en práctica un proceso creativo?}

Tiene que interesarme el espacio donde se instalará la obra, he de encontrar un punto de interés o motivación que tenga que ver con el espacio en sí mismo. Cada vez es más importante para mí que haya posibilidades de intervención, que puedan ser diferentes y/o de crear itinerarios, o maneras de encontrarse con la obra, para el receptor o visitante de la muestra, que le resulten menos usuales. El espacio moldea la conciencia del receptor, eso ya es un fin en sí mismo.

Presto mucha atención a la forma del edificio donde tendrá lugar la intervención, a veces simplemente las sugerencias formales de este pueden desencadenar un proceso creador con un buen resultado.

Otra condición es que haya una historia, un sedimento narrativo al cual recurrir, o que, desde las condiciones o situación del lugar, pueda iniciarse algún desarrollo que conecte con las ideas con las que trabajo habitualmente.

\section{4) ¿Tiene un modo de trabajo definido o este varía según la obra?}

Tendría que diferenciar entre dos clases de procesos por su destino, aquellos que van a tener una resolución espacial, que están destinados a hacer uso de una arquitectura, que englobaría en el formato de instalación o intervención, y otros que van a quedar configurados en un formato concreto: pintura, dibujo, texto, vídeo, etc., que tendrán vida más allá del espacio pensado inicialmente.

En ambos casos, igualmente me es necesario un conocimiento del lugar donde se va a desarrollar ese proceso creativo o su consecuencia. Es siempre preferible el conocimiento in situ del espacio. Para mí, resulta cada vez más importante que el trabajo sea adecuado al lugar, actúe sobre él y este no sea un mero continente de aquello que se hace en el estudio. En el caso de una instalación, puede incluso ocurrir que no aporte ningún material y trabaje con lo que me encuentre en el espacio a intervenir o en sus inmediaciones. La obra debe activar el espacio y el espacio determinar el efecto de la obra. Un diálogo y una coordinación entre ambos son vitales para que el resultado no sea fallido. Lo que intento es "sorprender al espacio", en el sentido de que este suele estar acomodado a unos usos, que no siempre son los que mejor resultado obtienen de sus posibilidades.

Cada vez doy mayor importancia al paso del tiempo como factor de maduración de la idea. Los casos en que no hay plazos concretos de entrega o me puedo permitir tomarme todo el tiempo que quiera, son los que prefiero. Me permiten distanciarme de los recursos que ya conozco, enriqueciendo mis posibilidades futuras. Podría recordar ahora la expresión de Joan Miró, cuando afirmaba trabajar como un jardinero, dejando que cada obra creciese y alcanzase su madurez, fertilizando aquí, podando allá, etc. Algunos de mis mejores proyectos surgen así, de un tiempo de elaboración lento, incluso cinco o más años desde la primera idea.

En mi proceso, es importante estar constantemente anotando, apuntando cualquier idea por insignificante que parezca. Como resultado tengo un buen número de blocs de notas a los que puedo recurrir en el caso de que se me demande una intervención y no disponga de los plazos largos de elaboración que prefiero. Tengo tres clases de blocs de anotaciones. Uno son los blocs de Canson ( 22 x $28.5 \mathrm{~cm}$ y 100 páginas), en los que anoto cualquier idea que me venga a la mente o la idea básica de algún proyecto que tenga en marcha, a 
menudo apoyando el texto en imágenes y en los que trabajo generalmente por la noche. Cuando un proyecto o exposición es aprobada, recurro a otra clase de bloc con menos hojas y usualmente de un tamaño A4. Y, por último, tengo la costumbre de llevar conmigo pequeñas libretas, especialmente cuando preveo que vaya a tener momentos muertos o de espera en los que, tengo comprobado, acuden buenas ideas.

\section{5) ¿Cree que hay diferencias entre la creación artística y otros tipos de creación, por ejemplo, la creación científica, industrial, etc.?}

Creo que las diferencias vienen dadas por el distinto destino del trabajo. En la creación científica o industrial las necesidades utilitarias son más decisivas que en la creación artística. La creación artística puede dejarse definir, simplemente, como poética sin disponerse necesariamente a ser interpretada ni comprendida. La creación que se relaciona con una producción industrial o científica puede hacer uso de cualquier procedimiento poético, intuitivo, artístico, pero no podrá cerrarse en estos procesos por útiles y hermosos que resulten. Podría recordar aquí la expresión de Maxwell, descubridor del electromagnetismo, quien afirmaba que, si una ecuación resultaba hermosa en su formulación, a menudo, también, acababa por ser cierta y exacta.

La creación artística no se debe en principio a ninguna utilidad (aunque esto sería discutible), lo cual la hace más libre y por tanto más poderosa. Y, precisamente por eso, los métodos de acercamiento al logro artístico son a menudo remedados o utilizados por no pocos científicos e ingenieros en sus búsquedas. Por ejemplo, la técnica empresarial de la "tormenta de ideas" es muy parecida a las técnicas de utilización del caos propia de algunos artistas.

\section{6) ¿Cree que hay diferencias en el proceso creativo de las diferentes artes?}

En mi opinión las diferentes artes utilizan, por las mismas razones que expuse en la pregunta anterior, parecidos procesos creativos. Aparte quedan las diferencias individuales y alguna especificidad propia de artes muy técnicas, que han de tener en cuenta la seguridad de su obra, como es el caso de la arquitectura, o el tener en cuenta a un equipo de colaboradores muy amplio, como en el caso del cine.

El hecho de que sean tan frecuentes los creadores que pueden estar activos y ser eficaces en distintas artes demuestra cuan próximos pueden estar los procesos creativos entre estas. Es mucho menos frecuente un artista, del campo que sea, que además resulte un buen científico, o ingeniero industrial, salvando casos excepcionales como el de Leonardo da Vinci, etc.

\section{7) ¿Adónde pretende llevar a su/s receptor/es?}

Lo cierto es que no estoy muy seguro de quererlo llevar a algún lugar. Pero, sí sé que quiero proporcionarle una experiencia que sea tan compleja, profunda o sentida como pueda darse desde mi experiencia y conocimiento.

Me doy cuenta de que, de cualquier forma, me interesa buscar puntos de contacto con el receptor, reducir la distancia entre este y el arte contemporáneo, ante el que suele haber cierto rechazo. Mostrarle cómo este nació del mismo mundo cotidiano y de las mismas preocupaciones que dominan su vida. 


\section{8) ¿Su creación artística es un acto de expresión, de comunicación, o las dos cosas?}

En mi opinión, un buen acto expresivo es comunicativo, da cuenta de algo, y de un modo que resulta accesible a algún nivel, aun para aquellos que no parecen especialmente predispuestos para una aceptación sin concesiones. Pienso, en este sentido, en el Guernica de Picasso que, siendo como es formalmente arriesgado y difícil, comunica un mensaje de modo tan claro que cualquiera puede darse cuenta de que se refiere al dolor y sufrimiento provocado por la guerra, haciéndolo extensible a todas ellas, más allá de su tema de partida. O, en cómo durante la Edad Media se utilizó con eficacia la imagen, extraordinariamente expresiva, para comunicar al vulgo ideas religiosas de calado, sin contar con su nivel cultural.

Una obra artística que no sea capaz de establecer comunicación, de hacer llegar un mensaje, pierde la posibilidad de ser útil al receptor y, por tanto, aumentan las posibilidades de que caiga en el mero entretenimiento o que sea fácilmente banalizada. No debemos olvidar que ya Platón especulaba con la idea de que la obra de arte debiera ser útil además de bella. El mero goce estético no es suficiente, si no va acompañado de otras apreciaciones, éticas, sociales, religiosas, etc.

Intento, en lo posible, aproximar mi creación al receptor, aunque siempre contando con que los receptores son numerosos y muy diferentes, sin olvidar que la recepción fina y especializada es escasa. Así que busco técnicas para envolver o implicar al receptor en la obra, por ejemplo: utilizar objetos o elementos que él ya conoce, que forman parte de su vida cotidiana, que no son estrictamente artísticos, ni nobles ni distantes. Este es un recurso que ayuda a hacer más corta la distancia entre la obra y el espectador. Además, utilizar la palabra escrita, los juegos de lenguaje, el humor, el erotismo, formas simples y directas sin demasiada elaboración en la composición, técnicas sencillas como girar un elemento $90 \mathrm{o}$ 180 grados y con eso cambiar por completo su significado (un muro se convierte en una pasarela si lo giramos 90 grados), y de ese modo pasa de ser un objeto nuevo, que separa y aísla y pone en comunicación.

\section{9) ¿Cree que el receptor completa su proceso de creación?}

Más que creer que lo completa, quisiera creer que lo hace, porque eso daría más valor e interés a nuestro trabajo, que se vuelve cada vez más penoso, solitario e inútil. En mi opinión, y tengo motivos para creer que es un pensamiento extendido, el receptor se ha vuelto mayoritariamente pasivo y demasiado ávido de novedades y entretenimiento como para tener un papel claro en el "redondeo" de la obra.

Para que el receptor pueda completar el proceso de creación parece lógico que disponga de un bagaje cultural o, en su defecto, de una actitud de respeto, cuando no de veneración, hacia la obra artística; y si, como ocurre a mi entender, ninguna de estas virtudes se está dando en esta época, tan dada a entretenerse y tan enemiga del pensamiento y la profundidad, la hermosa y emocionante experiencia de sentir la obra completada por el espectador, veedor o receptor es más rara aún que en los tiempos fundacionales de la modernidad. Entonces incluso el rechazo, la incomprensión, el ataque intelectual o físico a la obra tenían un valor real para completarla, para darle entidad y eficacia. En su lugar, ahora encontramos una falta de reacción, más allá de la meramente vinculada al pasatiempo, que da cuenta de lo que realmente parece que pasa: ya no se ve la obra artística como un medio privilegiado de 
conocimiento, de conocimiento del mundo y de uno mismo y de transformación de ambos. El creador sabe que hoy la (obra) es un objeto de consumo, generalmente rápido y que, por tanto, la comunicación, ni mucho menos la "colaboración" mistificante, con el receptor le está vedada por el signo de los tiempos.

Montserrat Palacios Prado ${ }^{12}$. Cantante, etnomusicóloga y artista sonora.

\section{1) ¿Qué es para usted la creación?}

Es entrar en uno mismo para encontrar lo que no se sabía que estaba ahí dentro y que siempre ha sido parte de uno mismo, siempre nuevo, siempre cambiante, siempre en continua construcción, pero dentro, aguardando el momento de ser atendido, ser escuchado. Dentro y, sin embargo, siempre mostrándose, exhibiéndose a trozos, en pequeñas porciones, en ciertas miradas, en los pasos, en los andares, en el modo de sonar, de reír, de cantar, de hablar, de gemir. La creación está presente en cada acto, en cada silencio, con nosotros, desde nosotros y a pesar de nosotros.

\section{2) ¿Cree que hay momentos diferenciables en este proceso?}

Diferenciaría la creación, del acto creativo. La creación me sucede, no me necesita y siempre está. El acto creativo, sería la toma de consciencia de un momento preciso de la creación en el que deseo detenerme, dar forma, construir un algo "materializable". A ese momento que intento aprehender, se le suele llamar "idea", esta se mira, se desnuda, se huele, se escucha y se reescucha, se le da forma, se le cose un vestido, se le arranca el vestido, se le pintan alas, se le rompen las alas, y se transforma en algo, que ya no es totalmente lo que imaginábamos que sería; la creación siempre sorprende al acto creativo, el resultado no es más que música de la experiencia y acto puesto en relación, momentos diferenciables de un proceso nunca terminado porque es la oreja del otro quien continuará dando forma al acto, como vasos comunicantes más que como un jarrón de agua estancada.

12. (México/Valencia). Estudió canto lírico en la Escuela Superior de Música (INBA-México) y etnomusicología en la (UNAM-México), donde se graduó con una investigación sobre polifonías vocales de tradición oral (Canto cardenche). Es doctora por la Liberis Artium Universitas (España), y doctoranda por la Universidad de Valladolid. Es creadora y directora del Centro de Investigación, formación, creación y experimentación sonora "El cant del cantó".

Diferentes performance vocales en Galerías de arte, salas de concierto, tornavoces de iglesias, montes, monasterios y calles destacando: Festival Fase en el Teatro de la Villa Elisabeth (Berlín), Festival Langen Nacht del Kultur (Kaiserslautern), Gallery Skolka (Praga), Abadia de Götweig (Austria), Parc de la Champagne Pastre (Marseille), Chiesa di San Marco (Castiglione di Sicilia), Centro Cultural de España (México), Sala de las Alhajas, La Casa Encendida, Teatro de la Abadía (Madrid), MACBA (Barcelona), CCCOCtubre, Instituto Francés, Centre del Carmen (Valencia), etc.

Su trabajo vocal se caracteriza por la interacción con objetos cotidianos en interacción con diversas técnicas vocales (Extended voice, canto lírico, experimentación, improvisación vocal y tradiciones vocales del mundo).

Su trabajo vocal ha sido referido en la prestigiosa Contemporany Music Review, 2019

Coautora con Llorenç Barber de La Mosca tras la oreja, De la música experimental al Arte Sonoro en España (SGAE), y autora de Cuando suena una campana, suena un mundo (EuDeba, Buenos Aires) y Campanas Quisqueyanas (AECID, Sto. Domingo). 


\section{3) ¿Qué condiciones requiere para poner en práctica un proceso creativo?}

Ninguna, el proceso creativo ocurre a veces sin yo ser consciente de ello, podría crear con cualquier elemento y en cualquier circunstancia. Es la idea, la imaginación la que me asalta, de pronto, sin importar donde me encuentre. Por supuesto es más fácil cuando se tiene un motivo, cuando te piden algo específico sobre qué poner en marcha la imaginación, y para eso se necesitarán determinadas condiciones que hagan posible materializar lo que se escucha. Pero esas serían condiciones materiales para dar forma a la obra más que al proceso. Si pienso en el proceso en sí, en mi caso, solo requiero imaginación y escucha.

\section{4) ¿Tiene un modo de trabajo definido o este varía según la obra?}

Sí, en términos generales, tengo un trabajo definido, que empieza por la concreción de una o varias ideas y su forma en el espacio. Mi trabajo suele ser siempre muy intuitivo y también muy performático, así que pienso en ciertos trayectos, movimientos y elementos en el espacio, situación del público, etc.; por lo que casi siempre me facilita hacer una partitura visual en papel, de mis movimientos, de los elementos que vaya a utilizar para determinada obra (tierra, plumas, copas de cristal, teteras, máquina de coser, etc.), y de la acción sonora con estos elementos, como imágenes acústicas. La partitura solo me funciona como una estructura general muy abierta. Como me gusta trabajar con símbolos, donde cada elemento tiene una importancia específica, suelo documentarme teóricamente sobre algunos aspectos que quiero trabajar, y cuando todo se acaba de escribir sobre ello.

\section{5) ¿Cree que hay diferencias entre la creación artística y otros tipos de creación, por ejemplo la creación científica, industrial, etc.?}

Claro que hay diferencias, y también muchas similitudes. En términos generales, toda creación, sea artística, científica o industrial busca la belleza, la liberación y la utilidad; hay obras científicas de una belleza apabullante y obras artísticas de una utilidad social impresionante. Sin embargo, son sus procesos creativos, diría yo, sus "modos de hacer", y no solo sus fines o resultados específicos los que marcan la diferencia.

6) ¿Cree que hay diferencias en el proceso creativo de las diferentes artes?

No solo en las diferentes artes, sino en los diferentes artistas de cada arte, el proceso creativo puede tener puntos comunes, ciertos anclajes, incluso obligados para conseguir ciertas obras; pero, aun así, el proceso creativo es muy subjetivo, y son esas sutilezas personales, esas intuiciones que nacen en una mente y no en otra, esos rasgos que se parecen pero que no son iguales, los que marcan el cambio, los caminos y los paradigmas. Lo paradójico es que, aunque subjetivos, siempre son el regurgite de lo colectivo.

\section{7) ¿Adónde pretende llevar a su/s receptor/es?}

A dónde ellos quieran. De hecho, yo no los llevo más que a los sitios donde sus prejuicios, sus propias experiencias, sus referentes, sus códigos, su interpretación, se los permitan. Por eso la obra de arte y en general todo el universo y hasta nuestros mejores amigos, familias y amantes, son siempre nuestra interpretación, nunca llegamos a conocer a nada ni a nadie, siempre interpretamos desde nosotros. Tú me escuchas y me defines y describirás mi obra de forma muy diferente a cómo lo hiciera un inuit o un pigmeo africano, incluso a cómo lo hubieras hecho tú hace veinte años, o cómo lo haría tu alma gemela en este preciso momento. 


\section{8) ¿Su creación artística es un acto de expresión, de comunicación, las dos cosas?}

Las dos cosas. Y me gusta pensar que, además de expresar y comunicar, permite trascender, en el sentido en que posibilita atravesar el límite que nos separa, buscar la esencia de las cosas, ser aire con todos. La voz es de las mejores herramientas sonoras para conseguirlo.

\section{9) ¿Cree que el receptor completa su proceso de creación?}

Sin duda.

Ana María Rocha Puente ${ }^{13}$. Artista y escritora.

\section{1) ¿Qué es para usted la creación?}

La creación artística, para mí, implica un proceso en el que, partiendo de una determinada intención, se obtiene un resultado o una obra, sea esta de naturaleza conceptual o material o todo junto. No existe la creación absoluta; siempre alguien (sea individual o como conjunto social) ya antes se planteó de algún modo una intención semejante; por ello, el resultado obtenido podrá tener coincidencias con otros, pero siempre será de alguna manera distinto. Así habría en la creación, en general, un aspecto que pertenece al yo creador y otro a un nosotros (generación, comunidad histórica o social, etc.). La sociedad, el tiempo y la cultura siempre serán determinantes de algún modo, no podemos escapar a ello.

En la creación artística todas mis experiencias, sentimientos, conceptos se integran en una amalgama que contribuye a la obtención de un resultado, que puede aparecer con mucho esfuerzo o de golpe llamarse 'iluminación'; pero no es más que el resultado, muchas veces, de experiencias o ideas fracasadas o abandonadas, según sea el caso. Tanto el proceso como el resultado para el creador pueden ser de fascinación o de alguna forma de angustia. Creo que una buena metáfora de lo anterior es la del tejido: la urdimbre sería todos aquellos aspectos de la creación que escapan al yo creador y que es la "base" para la creación individual (contexto social, cultural e histórico, experiencias y obras realizadas por otros, etc.). La trama es lo que vamos construyendo con nuestra intención, y allí se filtra nuestra vida, gustos y experiencias personales. La primera (la urdimbre) es el soporte no individual de la creación, nos proporciona los insumos generales que van formando y determinando la trama que construiremos. Pero es el creador el que construye la trama y el resultado final, lo que alcancemos y definamos como "nuestra" creación.

13. Estudió Lengua y Literatura en la Pontificia Universidad Católica del Perú, obteniendo la Licenciatura en Literatura Hispanoamericana (2012). Así mismo hizo estudios de escultura en la Escuela Nacional de Bellas Artes y dibujo en talleres de artistas como Cristina Gálvez.

Sus intereses giran en torno a la literatura y a las artes plásticas. Ha dedicado gran parte de su vida profesional a la docencia de jóvenes en el campo del diseño y el arte. Ha participado en exposiciones individuales y colectivas de pintura y grabado. Realizando también algunas incursiones en la escultura.

Ha colaborado en publicaciones, como en el libro Sabino Spingett (Universidad Peruana de Ciencias Aplicadas, 2015) y El gesto en el vacio (Centro Cultural de la Pontificia Universidad Católica del Perú, 2009), edición dedicada a la escultora Cristina Gálvez. Recientemente, en febrero, publicó un libro de poesía: Donde habitas. Edición Independiente, Lima, 2020, con textos acompañados por ilustraciones, obra que sintetiza dos importantes modos de creación personal el literario y el visual. 
Así que, aunque no quisiéramos, la urdimbre está allí y es necesaria para marco de la creación individual; y será muy variable el modo cómo se integre en la obra individual.

\section{2) ¿Cree que hay momentos diferenciables en este proceso?}

Sí, hay momentos diferenciables. Pero lo que puede variar en el proceso es el ritmo o la secuencia en que se van presentando, también los tiempos que van ocupando. Generalmente, tenemos un primer momento de ideación o germinación de una intención, otro de investigación y desarrollo, hasta finalmente el cierre del proceso que implica un resultado. Esto lo indico como una secuencia temporal lineal, pero realmente es mucho más complejo, y cada "momento" es en sí un pequeño proceso donde la linealidad se rompe y aparecen círculos o líneas paralelas.

La germinación no es muchas veces instantánea, sino producto de otros conceptos o ideas que han sido descartados o remodelados. También puede ser producto del entusiasmo de un instante que luego se evalúa emocional o racionalmente y por último se transforma. El concepto inicial siempre se va transformando durante el proceso mismo, como una planta que se ve enriquecida por ramas y hojas; pero también la planta puede desfallecer.

El proceso nos va llevando por caminos no lineales. El inicio del proceso creo que muchas veces es accidentado y frustrante; no olvidar a Vallejo con su "Quiero escribir pero me sale espuma. / Quiero decir muchísimo y me atollo"... aplicable a todos los procesos creativos. Pues es el primer intento de tratar de concretar la búsqueda y es el enfrentarse al famoso "vacío" del papel o al "silencio" en general. Frente a la búsqueda de concretización de una obra, hay muchas opciones que influyen: desde la técnica elegida con sus límites y posibilidades hasta nuevas experiencias, percepciones o ideas que encontramos en el camino. Cuando se avanza en el proceso y la trama empieza a fluir, es satisfactorio, pero nada ni nadie asegura que se llegue a un buen fin.

Por ello, el resultado final muchas veces es distinto a lo pensado inicialmente, dependiendo de lo flexibles que seamos, pero también puede suceder que perdamos la conexión con lo buscado, abandonando el camino o encontrando otra cosa.

\section{3) ¿Qué condiciones requiere para poner en práctica un proceso creativo?}

Las condiciones van desde lo psicológico y espiritual (motivación interna profunda, entusiasmo por una idea o concepto a explorar, tranquilidad, distanciamiento de los otros) hasta lo económico (desligarse de los problemas de ese tipo, no pensar en el día a día).

A veces también uno tiene pequeños o grandes ritos... tomar café, dar una vuelta o escuchar una determinada música. Por ello el proceso creativo es un proceso que tiene que lidiar con obsesiones, angustias y placeres grandes o pequeños, rutinas, fastidios y deslumbramientos.

\section{4) ¿Tiene un modo de trabajo definido o este varía según la obra?}

Creo que todo esto también es variable. A veces cuando uno cree/siente que está "como inspirada" es mejor escribir o dibujar casi mecánicamente. Luego es recomendable dejar pasar un tiempo y corregir; creo que el tiempo es un buen corrector en el sentido que permite distanciarse de la obra en proceso, verla con otros ojos; con otros ojos pues algo de uno se ha transformado en ese tiempo. Hay que tener en cuenta en muchos procesos las incontables revisiones que hastían; uno debe saber ponerles un límite... Leí una vez de un autor que, estando ya su libro en venta, iba a revisarlo a una librería y pensaba en corregirlo. 
5) ¿Cree que hay diferencias entre la creación artística y otros tipos de creación, por ejemplo la creación científica, industrial, etc.?

Aunque las etapas del proceso pueden ser semejantes, hay en la creación industrial, científica o incluso de diseño gráfico otros aspectos. Por ejemplo, este tipo de creación parte de una necesidad externa al individuo o grupo creador, un problema que resolver y que atañe más a otros que al creador mismo. Además, estos tipos de creación implican proyectos grupales con dinámicas distintas e incluyen procedimientos como los focus groups y otros poco utilizados en la creación artística.

\section{6) ¿Cree que hay diferencias en el proceso creativo de las diferentes artes?}

Hay ciertas diferencias por los medios y técnicas elegidos y ello determinará los resultados. Pero en todos los casos lo que hace la creación artística única es tratar de decir algo de una manera personal y diferente.

La literatura, al usar la palabra, tiene como recurso un código que es el lenguaje verbal, común a toda una comunidad. Y ese código de tan aparente inmediatez, tiene que liberarse justamente de lo "común" para volverse distinto y novedoso y así seducir o impactar al receptor. He ahí lo complejo.

En las artes visuales o plásticas nos encontramos frente a códigos secundarios, que hay que aprender de ex profeso y tratar de manejar/dominar para alcanzar una técnica expresiva. La técnica determina los límites y alcances de la expresividad y comunicabilidad ejercidas por el creador en el proceso creativo. Por ejemplo, si no manejo el intaglio, no puedo hacer casi nada, a no ser que convierta ese casi nada en algo expresivo, pero con límites marcados.

\section{7) ¿Adónde pretende llevar a su/s receptor/es?}

El receptor deberá encontrar en la obra pequeños o grandes hitos de interés o deslumbramientos, de placer o desagrado, pero encontrar algo. Debería ayudar a develar de una nueva manera de sentir /pensar el mundo: ¿...eso era así, cómo lo había sentido/ pensado? De lo contrario, nada sirvió.

Por ejemplo, he terminado de leer Informe sobre la Ceguera de Saramago. Al principio no tenía interés en hacerlo, pues el mundo de la ceguera me es incómodo. Pero leyéndolo encuentro que logra con una mezcla de intensidad y de sutileza, abrirnos a una nueva visión del hombre y su "ceguera mental". También estuve releyendo la Historia Universal de la Infamia de Borges, y allí lo que después de tiempo me parece deslumbrante, es su manera de usar el lenguaje -rico y barroco- que transforma lo "infame" en seductor.

\section{8) ¿Su creación artística es un acto de expresión, de comunicación, o las dos cosas?}

Uno puede dar énfasis a cualquiera de los dos aspectos. Pero pienso que en el autor pesa más la expresión y en el receptor la comunicación.

\section{9) ¿Cree que el receptor completa su proceso de creación?}

Sí. El lector, como diría Eco, es también un creador, pues recoge de la obra lo que le interesa, llena cabos sueltos, se deslumbra por una parte o aspecto de la obra o la desecha, la hace vivir según su propia vida. 
Eso es lo bello de la creación artística: que alguien se apropie de ella, la recree, la odie, la ame, la aprecie, te haga reflexionar; pero que no te sea indiferente. La obra cobra así vida propia y transciende a quien la creó.

Olga Verme-Mignot ${ }^{14}$. Artista. Especializada en grabado.

\section{1) ¿Qué es para usted la creación?}

Es una mirada sobre la realidad.

\section{2) ¿Cree que hay momentos diferenciables en este proceso?}

Sí, la reflexión, la realización, su evolución en el tiempo en función de los sentimientos y lo vivido.

\section{3) ¿Qué condiciones requiere para poner en práctica un proceso creativo?}

La tranquilidad para mirarme a mí misma y al mundo exterior.

\section{4) ¿Tiene un modo de trabajo definido o este varía según la obra?}

Siempre es el mismo y, en grabado, cada técnica tiene un proceso creador diferente.

5) ¿Cree que hay diferencias entre la creación artística y otros tipos de creación, por ejemplo la creación científica, industrial, etc.?

En todos hay la relación con el mundo y la realidad, lo que los diferencia es la finalidad: la reflexión, el cambio, el progreso, la diversión.

\section{6) ¿Cree que hay diferencias en el proceso creativo de las diferentes artes?}

En principio no, la diferencia está en cada artista.

\section{7) ¿Adónde pretende llevar a $\mathrm{su} / \mathrm{s}$ receptor/es?}

A una reflexión sobre la realidad.

14. Nace en Lima, Perú en 1948. Reside en Francia desde 1982. Estudios de Sociología en la Universidad Católica en Lima y el Doctorado en Sociología Política en la Escuela de Altos Estudios en Ciencias Sociales en París.

Inicia sus estudios de pintura y dibujo en la Escuela Nacional de Bellas Artes en Lima en 1980 y 1981, continuando en París en la Academia Beaubourg en 1984 a 1986.

Realiza estudios en grabado en los talleres de la Escuela de Bellas Artes en Nancy y en los Talleres de Bellas Artes de la Municipalidad de París en Montparnasse. Desde 2004 miembro del Taller Colectivo de Grabado de la "Cuidad Internacional de Artes" en París. A partir de 1992, muestra sus creaciones en pintura y grabado, participando en exposiciones en París, Lima, Cajamarca (Perú) y en concursos y bienales en Italia, España, Argentina, Rumanía, Japón y Francia. Ha realizado libros de artista en colaboración con poetas peruanos, franceses, alemanes, en los cuales ha expresado sus preocupaciones y miradas sobre la vida.

En su trabajo como grabadora, ha expresado las miradas que ha interiorisado en el transcurso de su vida, y las miradas sobre la realidad, expresadas esta vez a través de los paisajes peruanos y franceses, e igualmente en los objetos y frutos simples que se encuentran en nuestro entorno. 


\section{8) ¿Su creación artística es un acto de expresión, de comunicación, o las dos cosas?}

Las dos cosas.

\section{9) ¿Cree que el receptor completa su proceso de creación?}

Él le da su mirada, puede completarlo o destruirlo.

\section{José Villalba González ${ }^{15}$. Escritor}

\section{1) ¿Qué es para usted la creación?}

El ser humano, ese mequetrefe a merced de las fuerzas naturales, suele necesitar dioses en quienes confiar para enfrentarse a sus propios miedos. Pero, a veces, no le basta con inventar divinidades sino que, a través de un acto de rebelión muy productivo, hasta se decide a imitar el poder creador de tales deidades. En ese empeño, una de las fórmulas más socorridas y, desde luego, más gratificantes, tiene que ver con la creación de carácter artístico o de cualquier otra orientación y finalidad. Por ese camino, los humanos hemos alcanzado grados virtuosos de elaboración sensible, o bien hemos explorado prodigiosos campos de aplicación práctica. El grado de civilización de los pueblos ha corrido siempre parejo a la creatividad de sus integrantes.

Ahora bien, si quisiera responder a la pregunta desde otro punto de vista, y de un modo más lapidario, bien podría decir que la creación es la espita a través de la cual ese patrimonio excepcional de los humanos, que es el ingenio, fructifica en la búsqueda del bienestar, a través de un desarrollo intelectual no pocas veces asociado a la aprehensión de la belleza en su sentido más profundo.

\section{2) ¿Cree que hay momentos diferenciables en este proceso?}

De un modo muy esquemático, primero nos llega la idea y luego nos enfrentamos a su desarrollo material. A la idea se accede a partir de una casuística muy variada, en la que con frecuencia interviene la casualidad; pero el desarrollo de esa idea exige en casi todos los casos un amplio bagaje técnico e intelectivo, parejo a las mismísimas facultades creativas, para que el proyecto solidifique con éxito. En el magma de emociones e intuiciones, que se desencadena durante el proceso creativo siempre, ha de estar también presente ese oficio que ponga a disposición del receptor un producto asimilable.

15. Nacido en La Línea de la Concepción (Cádiz) en abril de 1955. Desde muy joven interviene en actividades culturales y artísticas. Ha dirigido montajes escénicos y estrenado un par de piezas para café-teatro. En el campo del cine amateur obtuvo el Primer Premio del Festival de Cine de Sevilla, en la modalidad de Super 8, con el cortometraje Gotas de Rocío. Posteriormente dirigió el Taller de Cine del Cinematógrafo en el Exilio, entre cuyas actividades realizó numerosos cortometrajes. Propició la creación del Cinematógrafo Municipal de La Línea. Posee más de sesenta premios literarios, casi todos en la modalidad de relato. En 1992 publicó la novela breve Concertino y, en 1996 Cuando oscurece, accésit del Concurso de Novela Corta Ramón Sijé en Orihuela. Algunos de sus relatos, premiados aparecidos en publicaciones vinculadas a las entidades convocantes de los certámenes, fueron recogidos en un volumen titulado Literatura de competición, editado en 2002. Está incluido en la antología de narración breve titulada Café Negro. También ha publicado numerosos comentarios de Arte. Como columnista semanal de los diarios Europa Sur y La Verdad ha superado el millar de colaboraciones. Es miembro del Instituto de Estudios Campogibraltareños, adscrito a la Sección dedicada a Ciencias de la Información, Filología y Literatura. 


\section{3) ¿Qué condiciones requiere para poner en práctica un proceso creativo?}

Tiempo y motivación.

\section{4) ¿Tiene un modo de trabajo definido o este varía según la obra?}

Cada obra tiene sus exigencias y está sujeta a sus propias contingencias. El método de trabajo consiste, para mí, en gestionar de modo eficiente los vectores que entran en juego en cada ocasión (estilo, argumento, documentación, género, técnica, objetivos, etc., etc.) $\mathrm{y}$, por lo tanto, ese método de trabajo es tan variable como variables son los campos vectoriales que se den cita al efecto. Para decidirme a poner en marcha un proceso creativo, cada vez más parto de una imagen fugaz que me proporciona el azar. Entonces surge una especie de instinto que me dice que en ese instante late algo especial. El análisis de ese desencadenante despeja las claves de la percepción inicial y, a partir de ahí, arranca el hermoso decurso de darle carne a las ideas y de elaborar una estructura que le aporte coherencia/consistencia al producto. Cuando esas ideas ya han cobrado vida propia y se adaptan con naturalidad a las estructuras prefijadas, los pasos siguientes resultan aún más satisfactorios, porque son los mismos elementos agentes los que guían con mano firme los giros del proceso creativo; hasta se desencadenan pequeñas rebeldías, perfectamente comprensibles, por parte de estos elementos agentes (en mi caso, los personajes de las historias), que aconsejan al autor a modificar, si es preciso, las estructuras inicialmente trazadas. Por descender a lo concreto, y en el ámbito de la creación literaria, hablo de ese momento mágico en que los personajes empiezan a tomar decisiones por sí mismos: se han convertido en entes tan palpitantes que hasta asesoran al autor en la tarea de plasmar coherentemente sus actos y decisiones. Si los personajes son potentes, el autor tiene mucho que aprender de ellos mientras trabaja. Es un moldeo mutuo.

\section{5) ¿Cree que hay diferencias entre la creación artística y otros tipos de creación, por ejemplo la creación científica, industrial, etc.?}

Son distintos los objetivos y forzosamente han de ser diferentes los impulsos creativos, pero todos coinciden en contribuir al desarrollo de la esfera más distintiva del ser humano, la que tiene que ver con el mundo de las ideas y su aplicación a la atmósfera de los propios sentimientos y de las propias necesidades individuales o colectivas.

\section{6) ¿Cree que hay diferencias en el proceso creativo de las diferentes artes?}

Si las hay dentro de cada arte en general y dentro de cada autor en particular, imagínese en el maremágnum global de las distintas facetas artísticas.

\section{7) ¿Adónde pretende llevar a su/s receptor/es?}

Hay numerosos propósitos, distintos en las diferentes ocasiones, pero si tuviera que mencionar el más acentuado de todos ellos, debo admitir que es muy parecido al que presidió la obra de Molière: enseñar divirtiendo. Aunque reconozco que en muchos casos mis artefactos creativos contienen una diversión muy amarga y que mis didácticas, por la vía de la crítica social, adoptan frecuentemente una chocante ejemplaridad basada en los opuestos; por ejemplo, cuando para no resultar demasiado doctrinal, muestro las miserias 
del ser humano sin emitir juicios morales al respecto y dejo que sea el receptor del mensaje quien saque las conclusiones óptimas.

\section{8. ¿Su creación artística es un acto de expresión, de comunicación, o las dos cosas?}

Ambas, y, en algunos casos, incluso un acto de liberación. Más aún, un acto de individualización. Al fin y al cabo, una pulsión psicológica muy presente, entre quienes huyen del comportamiento gregario, es la necesidad de diferenciarse de los demás. La originalidad creativa es una de las herramientas más acrisoladas para conseguirlo.

\section{9. ¿Cree que el receptor completa su proceso?}

Tanto, y de una manera tan eficiente, que a veces me sorprenden los análisis que algunos lectores inteligentes hacen de mis proposiciones. Ven aspectos que estaban ahí, pero en los que no fui capaz de reparar conscientemente mientras los manipulaba. Mis personajes literarios son a veces unas criaturas muy enredadoras. 


\section{REFERENCIAS $^{16}$}

Duchamp, M. (1957). El proceso creativo. Presentación de M. Duchamp en Houston (Texas) en 1957, ante la Conferencia de la Federación Americana de Artes. Publicada en Art News, vol. $56 \mathrm{~N}^{\circ}$ 4. Traducción realizada por Alberto Montealegre B. del original en inglés y de la traducción al francés hecha por el propio autor.

Zweig, S. (2010). El misterio de la creación artística. Madrid: Sequitur.

\section{Referencias de interés (no citadas):}

Eco, U. (1985). Obra Abierta. Barcelona: E. Ariel.

Eco, U. (2011). Confesiones de un joven novelista. Barcelona: Lumen.

Hernández Belber, M. y Martín Prada, J.L. (1994). La recepción de la obra de arte y la participación del espectador en las propuestas artísticas contemporáneas. Revista Española de Investigaciones Sociológicas, REIS, 84. Monográfico sobre sociología del arte, 45 - 63.

Sanz Lobo, E. (2003). Procesos creativos problemas y arte. INARS, Congreso: La investigación en las artes plásticas y visuales (pp. 51-57).

Shiner, L. (2004). La invención del arte. Una historia cultural. Barcelona: Paidós Ibérica.

Tora, G.M. (2011). L'art comme création ou la règle de nier la règle. Contribution à une sémiotique de l'art". Nouveaux Actes Sémiotiques, 114. Recuperado de https://www. unilim.fr/actes-semiotiques/2616

Fecha de recepción: 16 de marzo de 2020

Fecha de aceptación: 30 de abril de 2020

16. Tal como se indicó al inicio del artículo, las referencias incluidas son un conjunto de obras que pueden interesar a las personas que se adentren en el tema de la creación artística, pero no constituye un marco teórico del texto. 